\title{
Movement and joints: effects of overuse on anuran knee tissues
}

\author{
Miriam Corina Vera ${ }^{1}$, Virginia Abdala ${ }^{\text {Corresp.. }}{ }^{2}$, Ezequiel Aráoz ${ }^{3}$, María Laura Ponssa ${ }^{\text {Corresp. } 1}$ \\ ${ }^{1}$ Unidad Ejecutora Lillo (UEL), CONICET-Fundación Miguel Lillo, San Miguel de Tucumán, Argentina \\ 2 Instituto de Biodiversidad Neotropical (IBN). UNT-CONICET, San Miguel de Tucumán, Argentina \\ 3 Instituto de Ecología Regional, Universidad Nacional de Tucumán, Yerba Buena, Tucumán, Argentina \\ Corresponding Authors: Virginia Abdala, María Laura Ponssa \\ Email address: virginia@webmail.unt.edu.ar, mlponssa@hotmail.com
}

Movement plays a main role in the correct development of joint tissues. In tetrapods, changes in normal movements produce alterations of such tissues during the ontogeny and in adult stages. The knee-joint is ideal for observing the influence of movement disorders, due to biomechanical properties of its components, which are involved in load transmission. We analyze the reaction of knee tissues under extreme exercise in juveniles and adults of five species of anurans with different locomotion modes. We use anurans as the case study because they undergo great mechanical stress during locomotion. We predicted that a) knee tissues subjected to overuse will suffer a structural disorganization process; b) adults will experience deeper morphological changes than juveniles; and c) morphological changes will be higher in jumpers compared to walkers. To address these questions, we stimulated specimens on a treadmill belt during two months. We performed histological analyses of the knee of both treated and control specimens. As we expected, overuse caused structural changes in knee tissues. These alterations were gradual and higher in adults, and similar between jumpers and walkers species. This study represents a first approach to the understanding of the dynamics of anuran knee tissues during the ontogeny, and in relation to locomotion. Interestingly, the alterations found were similar to those observed in anurans subjected to reduced mobility and also to those described in joint diseases (i.e., osteoarthritis and tendinosis) in mammals, suggesting that among tetrapods, changes in movement generate similar responses in the tissues involved. 
1 Movement and joints: effects of overuse on anuran knee tissues

2 Miriam Corina Vera ${ }^{1}$, Virginia Abdala ${ }^{2, *}$ Ezequiel Araoz ${ }^{3}$ and María Laura Ponssa ${ }^{1, *}$

3

4

$5{ }^{1}$ Unidad Ejecutora Lillo (CONICET-Fundación Miguel Lillo), Miguel Lillo 251, San Miguel de 6 Tucumán, Argentina.

$7 \quad 2$ Instituto de Biodiversidad Neotropical. UNT-CONICET, San Miguel de Tucumán, Argentina.

83 Instituto de Ecología Regional, Universidad Nacional de Tucumán, Yerba Buena,

9 Tucumán, Argentina

12 * Corresponding authors: María Laura Ponssa (mlponssa@hotmail.com) Unidad Ejecutora Lillo

13 (CONICET-Fundación Miguel Lillo), Miguel Lillo 251, San Miguel de Tucumán, Argentina, 14 and Virginia Abdala (virginia@webmail.unt.edu.ar) Instituto de Biodiversidad Neotropical. 15 UNT-CONICET. Miguel Lillo 205, San Miguel de Tucumán, Argentina. 
Abstract

Movement plays a main role in the correct development of joint tissues. In tetrapods, changes in normal movements produce alterations of such tissues during the ontogeny and in adult stages. The knee-joint is ideal for observing the influence of movement disorders, due to biomechanical properties of its components, which are involved in load transmission. We analyze the reaction of knee tissues under extreme exercise in juveniles and adults of five species of anurans with different locomotion modes. We use anurans as the case study because they undergo great mechanical stress during locomotion. We predicted that a) knee tissues subjected to overuse will suffer a structural disorganization process; b) adults will experience deeper morphological changes than juveniles; and c) morphological changes will be higher in jumpers compared to walkers. To address these questions, we stimulated specimens on a treadmill belt during two months. We performed histological analyses of the knee of both treated and control specimens. As we expected, overuse caused structural changes in knee tissues. These alterations were gradual and higher in adults, and similar between jumpers and walkers species. This study represents a first approach to the understanding of the dynamics of anuran knee tissues during the ontogeny, and in relation to locomotion. Interestingly, the alterations found were similar to those observed in anurans subjected to reduced mobility and also to those described in joint diseases (i.e., osteoarthritis and tendinosis) in mammals, suggesting that among tetrapods, changes in movement generate similar responses in the tissues involved. 


\section{INTRODUCTION}

The mechanical load raised by movement is a key factor determining the correct morphogenesis of tetrapod joints (Drachman \& Sokoloff, 1966; Roddy, Prendergast \& Murphy, 2011; Nowlan et al., 2010; Abdala \& Ponssa, 2012; Shwartz, Blitz \& Zelzer, 2013; Ponssa \& Abdala, 2016). Since the joint is a structure adapted for motion, the requirement of movement for its correct development is expected (Drachman \& Sokoloff, 1966). Previous studies have demonstrated that alterations in the correct movement of limbs can produce severe malformations during the ontogeny, including adult pathologies (Hosseini \& Hogg, 1991; Arokoski et al., 2000; Pitsillides, 2006; Nowlan et al., 2010, 2012, 2014; Abdala \& Ponssa, 2012; Kim et al., 2015; Ponssa \& Abdala, 2016; Ford et al., 2017; Verbruggen et al., 2016). The absence or reduction of movement in early stages of development produce similar phenotypical alterations both in free-living organisms, such as anurans (Abdala \& Ponssa, 2012), or in organisms living in "controlled" environments, such as mice (Coutinho et al., 2002; Kahn et al., 2009) or chicken (Sullivan, 1966; Murray \& Drachman, 1969; Hall, 1975; Hall \& Herring, 1990; Quinn et al., 1998; Pitsillides, 2006). Likewise, joint-tissues that are subject to extreme mechanical loads caused by overuse can suffers similar consequences (Shwartz, Blitz \& Zelzer, 2013) as was studied in bones and articular cartilage (Shwartz, Blitz \& Zelzer, 2013) tendons (Sharma \& Maffulli, 2005; Maeda et al., 2011), and menisci (Adirim \& Cheng, 2003). vulnerable to pathologies (Tidke \& Tidke, 2013). Each of its components, including bones, ligaments, tendons, menisci and articular cartilage, are involved in load transmission, thus the proper functioning of each structure is essential for the correct functioning of the joint (Clark \& Ogden, 1983; Ralph \& Benjamin, 1994). 
Tendons are pieces of connective tissue linking muscles to bones that generate the

60

61

62

63

64

movement initiated by muscle contraction (Kjær et al., 2006; Zelzer et al., 2014). These elements

are excellent biological models to study the biomechanical and morphological adaptations of connective tissues to movement (Vilarta \& Vidal, 1989; Feitosa, Vidal \& Pimentel, 2002). The biochemical properties of tendons and other collagenous connective tissues vary with age (Thampatty \& Wang, 2017), and seem to be correlated with morphological changes (Viidik, 1982; Shadwick, 1990). Previous studies usually focused on the differences in tendon properties related to age (Viidik, 1982), and on the effects of mechanical load on tendons at different ages in rats (Ingelmark, 1948), mice (Michna, 1984), humans (Kannus et al., 1997) and horses (Edwards et al., 2005). Ingelmark (1948) observed that the thickness of collagen fibers did not vary in rats of different age, but found differences in younger individuals subjected to physical training. At every age, tendon cells are able to react to changes in mechanical loads, and to alter the composition of their extracellular matrix, forming a fibrocartilaginous matrix (Benjamin \& Ralph, 1998). The fibrocartilage usually occurs where tendons wrap and insert bones (Benjamin, Tyers \& Ralphs, 1991; Vogel, 2003), and is maintained due to the mechanical stimuli acting on the joint (Ralph \& Benjamin, 1994; Carvalho \& Felisbino, 1999). Although tendons show good ability to adapt to loading and movement (Kannus et al., 1997), if the tissue does not have time to repair itself it may not adjust, leading to injuries (Selvanetti, Cipolla \& Puddu, 1997; Sharma \& Maffulli, 2005). Tendon pathologies have been often studied in the human Aquilles tendon (Kader et al., 2002; Cook et al., 2004; Maffulli et al., 2008) and are evident in animals subjected to great mechanical loads, such as physical exercises (Kannus et al., 1997; Kraushaar \& Nirshl, 1999; Thampatty \& Wang, 2017). Other structures vulnerable to age and mechanical alteration of the joint environment are the menisci and the articular cartilages, that also play a key role in 
82 the correct functioning of the knee-joint (Poole et al., 2001; Tomkoria, Patel \& Mao, 2004;

83 Senan et al., 2011; Sun et al., 2012). The articular cartilage in conjunction with the synovial fluid

84 provides a frictionless articulation, and absorbs and dissipates load (Poole et al., 2001). The

85 properties of the articular cartilage are provided by the extracellular matrix and its chondrocytes

86 (Senan et al., 2011). Within the articular cartilage, different zones can be recognized, with

87 different properties according to the mechanical requirements (Tomkoria et al., 2004). These

88 biomechanical properties provide perfect support for the normal movement of the synovial

89 joints, but also make it vulnerable to extreme mobility or immobilization (Ni et al., 2015). The

90 menisci also play a mechanical role as stabilizers and weight-transmitters in the knee (Clark \&

91 Ogden, 1983; Senan et al., 2011). The normal functioning of the menisci depends on their correct

92 biochemical composition, ultrastructural organization, matrix composition and cellularity (Senan

93 et al., 2011; Pauli et al., 2011). The number of cells in the articular cartilage and the menisci are

94 important parameters for inferring their degree of alteration (Tomkoria, Patel \& Mao, 2004) and

95 the capacity to heal the tissue (Pauli et al., 2011). Also, both structures are functionally related;

96 indeed, magnetic resonance images revealed that degeneration in the menisci is a potential risk

97 factor of osteoarthritis due to its close relationship with the articular cartilage (Sun et al., 2012).

Different exercises have distinctive mechanical requirements (Ebben et al., 2011) with specific effects over the skeletal tissue (Frost, 1994; Sharma \& Maffulli, 2005; Ebben et al., 2011). The saltatory locomotion mode of anurans is one of the most challenging among tetrapods, due to the mechanical stress raised (Lutz \& Rome, 1994; Peplowski \& Marsh, 1997;

102 Bennet, 2001; Nauwelaerts, Stamhuis \& Aerts, 2005; Přikryl et al., 2009; Astley et al., 2013, 103 2015; Astley \& Roberts 2012, 2014). Although jumping is the dominant locomotion mode in anurans (Přikryl et al., 2009), hopping, swimming and/or walking are also present (Emerson, 
105 1979; Jorgensen \& Reilly, 2013). In these animals, locomotion has been studied from a 106 biomechanical and anatomical perspective of the pectoral and pelvic girdles (Emerson, 1979;

107 Přikryl et al., 2009; Jorgensen \& Reilly, 2013; Fabrezi et al., 2014) and limbs (Kargo, Nelson \& 108 Rome, 2002; Nauwelaerts \& Aerts, 2003, 2006). Specific studies of the knee-joint and the 109 dynamics of its tissue are scarce (Hebling et al., 2014; Ponssa \& Abdala, 2016; Abdala, Vera \& 110 Ponssa, 2017) despite its important role supporting great mechanical loads. Accordingly, the 111 knee-joint of anurans is an excellent study case to observe the dynamics of knee connective 112 tissues (tendons, fibrocartilage and articular cartilage) subjected to intense exercise.

113 Here, we present new data of the effect of the mechanical stress in the anuran knee' joints 114 in species with different locomotion modes. Since the mechanical environment of limb joints 115 constantly changes with growth (Hamrick, 1999), we analyze these histological changes at 116 different ontogenetic stages, from metamorphs to adults in order to record the effects that 117 overuse causes on the tissues. To address these issues, juvenile and adult frog specimens were 118 trained on a treadmill belt on a daily basis for 2 months. Based on previous work we predict (a) 119 that knee tissues of frogs subjected to excessive exercise will deviate from the normal and 120 healthy state, (b) higher morphological damage in adults than in juveniles, considering that 121 younger tissues are presumably more adaptable (Brack et al., 2007; Bailey, 2001; Clark \& 122 Ogden, 1983; Senan et al., 2011, Thampatty \& Wang, 2017) and (c) more alteration in tissues in 123 jumper species compared to walkers ones. 
127 Sixty-seven specimens of five frog species were analyzed: ten juveniles and ten adults of

128 Leptodactylus mystacinus Burmeister 1861, seven juveniles and twelve adults of Rhinella

129 arenarum Hensel 1867, seven adults of Melanophryniscus rubriventris Vellard 1947, six

130 juveniles and five adults of Leptodactylus latinasus Jiménez de la Espada 1875 and four

131 juveniles and six adults of Phyllomedusa sauvagii Boulenger 1882. The juveniles were

132 recognized as individuals who have completed the metamorphosis, because they exhibit traits

133 that indicate the completion of the metamorphosis (See Gosner, 1960, characters of the mouth

134 and complete tail reabsorption), but they have not reached the adulthood size or sexual maturity

135 indicated by secondary sexual characteristics. Thus, assessment of sexual maturity and

136 identification of adult males were based on the presence of secondary sexual characters (e.g.,

137 colored vocal sacs, nuptial excrescences); sexual maturity of females was based on examination

138 of the gonads. Previous experimental studies were performed with laboratory animals (e.g.

139 Vilarta \& Vidal, 1989; Ni et al., 2015; Nagai et al., 2016), which allows the use of a high number

140 of specimens. However, laboratory animal's exhibit restricted movements during their lives due

141 to generally being confined to a box. In the present study, we used animals collected in the field,

142 thus allowing us to assume that their histomorphology was determined by their normal

143 conditions of mobility. The disadvantage is that the number of collected specimens is restricted,

144 thus deriving in a small sample size. Specimens were collected during summer in Tucumán (Res.

145 No.13-16), Salta (Res. No. 0308/14) and Jujuy (Res. No. 21/2012) provinces, Argentina. They

146 were housed at Instituto de Herpetología of the Fundación Miguel Lillo, in individual terrariums

$147(30 \mathrm{~cm} \times 20 \mathrm{~cm} \times 25 \mathrm{~cm})$, where they moved freely, and under laboratory controlled conditions

148 (temperature $24-29^{\circ} \mathrm{C}$ ). They were fed ad libitum with living insects (ants, crickets, cockroaches

149 and worms). All the specimens were healthy and without signs of previous injuries. Animals 
150 were weighed with a digital scale (Cen-Tech; \pm 0.01 gr) and sized (snout-vent length, SVL) with

151 a digital caliper (Mitutoyo CD-30C and CD-15B; $\pm 0.01 \mathrm{~mm}$ ) before and after the experiments.

152 Since both SVL and weight were similar before and after the trials $( \pm 6 \mathrm{~mm})$, we inform only the

153 initial data (Table 1). Specimens of each species with both weight and snout vent length similar

154 to those used for experiments were selected as control.

\section{Experimental design}

157 To observe the effect of the mechanical stress provoked by overuse of knee tissues, trials were

158 performed on a treadmill belt, following the current protocols designed to this end (Kovanen, 159 Suominen, \& Peltonen, 1989; Birch et al., 1999; Ni et al., 2015; Gao et al., 2017; Thampatty \& 160 Wang, 2017). We defined "overuse" as the excessive use of the joint when the frog is "over161 stimulated" to move. In nature, they often stay still (Reilly et al., 2015) unless they need to move 162 to escape from predators, find food, defend territories, or find couple to mate (Nauwelaerts, 163 Stamhuis \& Aerts, 2005). The treadmill belt is one meter long and exhibits a flat surface. It is 164 covered with a transparent polycarbonate box to prevent the escape of animals, while its lateral 165 wall is covered with scaling paper (Fig. 1). The specimens were kept in captivity for two days 166 before the performance trials. Specimens were stimulated to jump (jumper species: 167 Leptodactylus latinasus and Leptodactylus mystacinus, Jorgensen \& Reilly, 2013; Fabrezi et al., 168 2014) or walk (walker species: Melanophryniscus rubriventris, Phyllomedusa sauvagii, Rhinella arenarum; Manzano et al., 2013; Fabrezi et al., 2014) by the contact with an elastic band crossed 170 on the treadmill belt (Fig. 1), avoiding the stress that human contact could generate. Thirty-four 171 specimens were arbitrarily chosen to perform the trials and the remaining specimens were used 
172 as control (i.e., did not undergo the exercise routine, Table 1). Trials were performed twice a day,

173 during up to 10 minutes unless the frog reached the fatigue earlier. Fatigue was defined as the

174 failure to maintain force of a muscle that has been under load, and that is relieved by rest

175 (Johnson et al., 1996). During muscular fatigue, a cascade of physiological mechanisms occurs

176 (Gibson \& Edwards, 1985), provoking muscular pain and dyspnea, which are the principal

177 reasons to stop motion (Güell, Casan \& Giménez, 1996). After a series of previous trials, the

178 velocity of the treadmill belt was settled at $2.73 \mathrm{~cm} / \mathrm{sec}( \pm 0.25 \mathrm{~cm} / \mathrm{sec})$, being this the maximum

179 value allowing normal movement of specimens. These preliminary trials showed that velocity

180 could be kept constant for all the animals. Juveniles and adults were exercised at the same

181 velocity allowing to evaluate the effect of the same mechanical stimulus over the joint at

182 different stages. The time and distance of the trials are detailed in table 1. Experimental and

183 control animals were sacrificed with xylocaine viscous (Lidocaine Hydrochloride 10\%), fixed in

184 a $10 \%$ formaldehyde solution for 24 hours, preserved in alcohol $70 \%$. Selected species for our

185 study are composed by organisms whose life history is subject to r selection, often referred to as

186 r-strategists. They inhabit temporary ponds, which are unstable and unpredictable environments.

187 They have ability to reproduce quickly, produce many offspring, each of which has a relatively

188 low probability of surviving to adulthood. In the case of Melanophryniscus rubriventris, that left

189 not so many offspring, we used fewer specimens. The actual population trends of the species

190 used for this study are LESS CONCERN according to the IUCN red list of threatened species

191 (www. iucnredlist.org version 2017-3). Apart from softly inducing them to move twice a day,

192 specimens in captivity were maintained clean, healthy, with enough water and food (according to

193 the Amphibian Husbandry Resource Guide, 2012). In addition, we pay attention to ARRIVE

194 guidelines and to Guidelines for Ethical Conduct in the Care and Use of Nonhuman Animals in 
195 Research (CARE). Experiments were approved by the Ethical Committee of Facultad de

196 Medicina, Universidad Nacional de Tucumán (Res. No. 81962-2014).

\section{Histological analysis}

198 Sixty-seven knees, thirty-four from treated and thirty-three from control specimens 199 corresponding both to juveniles $(\mathrm{N}=27)$ and adults $(\mathrm{N}=40)$ (Table 1, Supp Mat $\mathrm{S} 1)$ were 200 extracted and decalcified with a 50\% citrate sodium-50\% formic acid solution. Samples were 201 immersed in sodium sulfate for 24 hours, and then immersed in a mixture of glycerin and acetic 202 acid for 48 hours. The material was afterwards dehydrated in a graded ethanol series and 203 embedded in Histoplast embedding medium. 7- $\mu \mathrm{m}$ thick serial sagittal sections were cut with a 204 rotary microtome (Microm HM 325) and stained with Hematoxiline-Eosine and Masson 205 Trichrome, the latter allowing to identify collagen fibers. Histological samples were observed under an optical microscope (Leica ICC 50 HD) and photographed with a Nikon Coolpix P6000 digital camera for the diagnosis. The focus was put on the following tissues that integrate the knee-joint: tendons, fibrocartilage, menisci and articular cartilage. Additionally, the growth zone

209 in the diaphysis was examined.

\section{Tissue Alterations Score}

211 To assess the effect of the experiments on the connective tissues, five parameters were

212 considered: (i) collagen fibers of the fibrocartilage (ii) collagen fibers of the tendons (iii) 213 roundness of the nuclei of the fibrocartilage (iv) arrangement of the collagen fibers of the 214 menisci and (v) hypertrophic chondrocytes. The structural changes observed were categorized in 215 a scoring system. Histological Scoring is a technique widely used in orthopedic research and 216 clinical veterinary (Movin 1997; O’Driscoll et al. 2001; Pritzker et al., 2006; Maffulli, 2008; 
217 Pauli et al., 2011). It is commonly used to show structural qualitative changes of tissue owed to

218 any factor (Movin et al., 1997; Ameye et al., 2002; Pritzker et al., 2006; Maffulli et al., 2008;

219 Pauli et al., 2011). In this study, two levels of structural or morphological changes were

220 identified, namely, Score 1 for slight changes and Score 2 for severe changes. Score 0 was

221 assigned to those tissues that showed a normal morphology. The tissue scoring is described in

222 table 2. This grading system is arbitrary and it does not represent fixed stages, however it is a

223 simple and direct, way to represent the effect of the experiments (Pritzker et al., 2006). Since it is

224 as accurately as possible, is one of the most used systems in this context (see quotations above).

225 Tissues were considered normal following Carvalho (1995) and Franchi et al. (2007) for tendons;

226 Benjamin et al. (1991), Benjamin and Ralph (1998), and Carvalho and Felisbino (1999) for

227 fibrocartilages; Pauli et al. (2011) and Senan et al. (2011) for menisci and Pacifici et al. (1990)

228 for hypertrophic chondrocytes. For an overview of the alteration state of each specimen, scores

229 of each trait were summed up. Specimens with Score 10 were those whose connective tissues

230 exhibited the highest levels of abnormality.

The association of the score of each trait with the treatment, the locomotor mode, the

232 species identity and the stage of the individual were assessed by using multinomial ordinal

233 logistic regression. The multinomial ordinal logistic regression is used for describing and testing

234 hypotheses about associations between an ordered categorical variable (i.e , the alteration tissues)

235 and one or more categorical or continuous predictor variables (i.e, treatment, locomotor mode,

236 stages and species) to predict the probability of occurrence of each category (Peng, Lee \&

237 Ingersoll, 2002). In the case of the shape of the hypertrophic chondrocyte where only two

238 classes were observed (0 and 2$)$ we used a simple logistic regression that is adequate to model

239 binomial responses. In all the cases we proposed a set of biologically sensitive models (e.g. lineal 
240 combinations of predictors) and we compared to what extent they were supported by our data.

241 The set of competing models were increasingly complex; they included an intercept model,

242 which assumes that the probability of observing any category is identical for all the individuals, a

243 model that only considered the treatment, different lineal combinations of the treatment with the

244 stage, the species and the locomotor mode and the interaction between treatment and the other

245 predictors. Locomotor mode and species were not included in the same model due to their

246 nestedness. The models were compared using their Akaike information criterion (AIC, Symonds

$247 \&$ Moussalli 2011. The AIC simultaneously evaluates the level of adjustment of a model

248 (maximum likelihood) with the number of parameters (i.e, an indicator of the the complexity of

249 the model). The AIC is not informative by itself and only has utility for compare different

250 models. $\triangle \mathrm{AIC}$ (delta of AIC) is used as a measurement of the distance of all the models that

251 explain a variable with respect to the model with the best AIC. Due to the nature of our data, we

252 used an AIC corrected by small samples (Burnham \& Anderson 2002). The best logistic models

253 were identified by minimum AIC (Burnham, Anderson \& Huyvaert, 2011). All the statistics

254 analyses were performed with the R studio software (version $0.99 .903,2016$ ).

\section{Menisci cell quantification}

256 To analyze the density of cells in the menisci, an area of $100 \mu \mathrm{m}^{2}$ of the knees of fifty-eight

257 specimens (30 treated and 28 control specimens) was selected (Fig. 2). The number of cells was

258 quantified with ImageJ software and the density was calculated $\left(\rho=\mathrm{n}^{\circ}\right.$ of cells/ area). The

259 normality and homoscedasticity of the data were tested with Shapiro-Wilk and Levene's tests.

260 Differences in the density of cells between control and treated groups were calculated with a

261 Mann-Whitney-U test using R studio software (version 0.99.903, 2016). 


\section{Articular cartilage}

264 To analyze the density of cells in the superficial and tangential zones of the articular cartilage,

265 the knees of twenty-five (13 treated and 12 control) juvenile specimens were used. Adult 266 epiphyses were not analyzed since their articular cartilage was not visible in our samples. The 267 zones of the epiphyses of the femur and tibia-fibula were divided in three areas: internal, medial 268 and external (Fig. 2). The number of chondrocytes was counted in each region with Image J 269 software, and the density was derived $\left(\rho=\mathrm{n}^{\circ}\right.$ of chondrocytes/ area). The normality and 270 homoscedasticity of the data were tested with Shapiro - Wilk and Levene's tests. Differences in 271 the density of cells between control and treated groups were calculated with a Mann-Whitney-U 272 test. A posteriori Kruskal - Wallis test was made to assess for differences among zones and 273 areas. R studio software (version $0.99 .903,2016$ ) was used for the statistical analyses.

\section{RESULTS}

\section{Microanatomy of the knee-joint}

The normal knee-joint of an anuran juvenile specimen (SVL $22.94 \mathrm{~mm}$ ) is formed by the

278 joint capsule, the menisci, the epiphyses of the femur and the tibia-fibula, muscles, ligaments, 279 and tendons (Fig. 3A). The joint capsule consists of fibrous and dense connective tissue, i.e. 280 fibrocartilage and tendons. The tendons exhibit parallel collagen fibers with abundant and round 281 nuclei (Fig. 3B). A spindle-shape fibrocartilage is present in the external surface of the knee over 282 the tibia-fibula epiphysis (Fig. 3A). The cells of the fibrocartilage present spherical nuclei, 
283 usually arranged in rows, and collagen fibers arranged in parallel (Fig. 3B). The meniscus is

284 present over and between the two epiphyses; the zones of attachment with the epiphyses 285 (enthesis) are usually fibrocartilaginous (Fig. 3C). The meniscus is fibrocartilaginous, with 286 collagen fibers usually packed or showing a more disordered pattern. The nuclei of the collagen 287 fibers of the meniscus are dispersed or arranged in rows (Fig. 3C). The epiphyses of the femur 288 and the tibia-fibula are cartilaginous and covered by the articular (hyaline) cartilage. The 289 chondrocytes of the articular cartilage are isolated or disposed in isogenous groups. The irrigated 290 osteochondral ligaments are located between the lateral articular cartilage and the periosteal bone 291 of the diaphysis (Fig. 3D). Internally, a cartilaginous graciella sesamoid is found between the 292 femur and the tibia-fibula (Fig. 3E). The m. gracilis major (Fig. 3E), m. extensor cruris brevis, m. 293 vastus internus and $\mathrm{m}$. gastrocnemius are mature at this stage. joint capsule with a big fibrocartilage over the surfaces of the tibia-fibula and of the femur (Fig. 4A). The cells of the adult fibrocartilage show round nuclei in rows, and parallel collagen fibers

297 (Fig. 4B), more ordered than in juveniles. Tendons are mature tissues, as evidenced by the parallels fibers and flat nuclei. The menisci are thicker than in juveniles and show areas with packed and laxer collagen fibers (Fig. 4C). The graciella sesamoid is cartilaginous with a center of endochondral ossification. The m. gracilis major is mature (Fig. 4D). The epiphyses are ossified, evidenced by the wide medular cavity with endochondral trabeculae, osteocytes, 302 osteoclasts and blood vessels (Fig. 4E). 
Scores are presented in figure 5 and a global overview of the altered tissues in juveniles

306

307

and adults are showed in figure 6 . The first column in figure 5 corresponds to the control specimens and the two right columns correspond to the overuse trials scores.

Normal fibrocartilages were composed by parallel packed collagen fibers between cells (Score 0, Fig. 5A). In treated specimens, there was a gradual separation of the collagen fibers, from a loose (Score 1, Fig. 5B) to a laxer arrangement (Score 2, Fig. 5C). Normal fibrocartilage cells showed round nuclei (Score 0, Fig. 5D). These exhibited a change to oval (Score 1, Fig. 5E) or flattening shape (Score 2, Fig. 5F). Tendons were formed by tightly packed collagen fibers (Score 0, Fig. 5G). Such as in fibrocartilages, tendons showed a gradual disarrangement of their collagen fibers from a loose (Score 1, Fig 5H) to a very loose pattern (Score 2, Fig. 5I). Normal menisci showed a loose pattern with collagen fibers separated from each other (Score 0, Fig. 5J). The menisci of treated specimens showed a slight (Score 1, Fig. 5K) or a maximum packing (Score 2, Fig. 5E) of their collagen fibers. The hypertrophic chondrocytes of the growth area diaphyses of both femur and tibia-fibula, normally showed an oval or round shape (Score 0, Fig. 5M). The cells exhibited a drastic change of shape, adopting a flattened shape (Score 2, Fig. 5O). This last feature was observed only in juvenile specimens because in adults the diaphyses are already ossified.

In the joint capsule of experimental juveniles, the cells of the fibrocartilages were very affected (Fig 7. B), and showed a flat or oval nuclei (Table 3). The fibers of the tendon showed a very lax arrangement (Score 2, Fig. 7C) or a slight disarrangement (Score 1, Fig. 7C, Table 3). The menisci fibers presented a packed arrangement (Score 2, Fig 7. D). The hypertrophic chondrocytes of the growth area of the diaphyses showed a severe flattening (Score 2, Fig. 7E, Table 3). 
Among adults, the fibrocartilaginous tissue showed more extreme changes (Fig. 7, Table

329

3). There was a noticeable separation of the collagen fibers of the fibrocartilage (Score 2, Fig. 7F) and the nuclei of the fibrocartilage cells were elongated (Score 2, Fig. 7G, Table 3). Tendons also showed a slight abnormal arrangement with a loose pattern of the collagen fibril (Score 1, Fig. $7 \mathrm{H}$ ).

The highest total sums of scores were 5 and 7 for one specimen of L. mystacinus and one adult specimen of L. latinasus, respectively. Both species have a jumper locomotion mode. The walker species also show tissue alterations, but the sum of their scores was 4 in a juvenile and an adult specimen of $P$. sauvagii and 4 in adults of $M$. rubriventris. A juvenile of Rhinella arenarum have a total score of 4 and an adult a total score of 6 . Scores distribution among species is detailed in Table 3 and figure 7.

In all the analyses the models that included the treatment outperformed the intercept model (more than two units of difference between their AIC). Some of the better models included also the stage (in fibrocartilage collagen fibers), the species (in fibrocartilage nuclei and collagen fiber of the tendon), and the stage and species (in menisci fibers and hypertrophic chondrocytes) (Table 4, Supp Mat S2). Neither the locomotor mode nor the interactions between explanatory variables were included in the winning models in any of the analyses. The probabilities estimated through the best models are detailed in table 5 . The probability of finding an alteration in the arrangement of the fibrocartilage fibers (score 1 or 2 ) increase after the treatment in juveniles and adults. The latter stage doubles the probability of presenting the score 2, from 0.07 to 0.14 (Table 5). The probability of showing a shape change in the nuclei of this tissue varies among the species and the treatment. The probability of showing the highest alteration (score 2) triples in L. latinasus, P. sauvagii and M. rubriventris. No differences in the 
351 probability were found between the stages. Regarding tendons, the probability of showing

352 alteration after the treatment also varies between species, in L. latinasus and L. mystacinus the

353 probabilities of showing the score 1 doubles, and in $R$. arenarum the probability of showing the

354 score 2, triples. For menisci fibers arrangement there is a slight effect of the treatment and a 355 strong effect of the stage (e.g. the probability of observing score 2 in L. mystacinus doubles

356 between stages, from 0.18 to 0.42 ). For hypertrophic chondrocytes shape the probability of 357 present alteration after the treatment varies also between stages and species. It is higher in 358 juveniles of L. mystacinus and adults of L. latinasus and P. sauvagii (Table 5)

\section{Menisci cell quantification}

The density of cells in the menisci was similar between experimental (i.e., overexercised $)$ and control individuals, both in juveniles $(\mathrm{U}=136 ; p=0.43)$ and adults $(\mathrm{U}=280.5 ; p$ $=0.98$, Fig. 8). Both in control and experimental specimens, the density of cells in the menisci was lower in adults than in juveniles.

\section{Articular cartilage cell quantification}

In the articular cartilage of juvenile stages, there were no significant differences in the in the femur $(\mathrm{U}=2578 ; p=0.38)$ nor in the tibia-fibula $(\mathrm{U}=3269, p=0.08)$ (Table 3).

\section{DISCUSSION}


Our results partially sustained the proposed predictions: tissues showed certain degree of

373 deviation from the healthy state. The collagen fibers of the tendon and fibrocartilage were the

374 knee-joint tissues showing phenotypical changes after the overuse trials. The fibers of the

375 menisci and the fibrocartilage showed the highest structural alterations in adults. It should be

376 noted that although evident, all these alterations are gradual. Finally all locomotor modes showed

377 similar response to the trials, contradicting thus our third prediction.

We infer that adults are more vulnerable to suffer morphological changes after

experimental trials. Interestingly, some jumper specimens present the highest score. We observed

a severe disarrangement of the collagen fibers of the fibrocartilage located over the tibia-fibula among experimental adults, while most experimental juveniles showed only a slight disarrangement. Interestingly, tadpoles with reduced mobility also presented a high disarrangement of the collagen fibers of the fibrocartilage (Abdala \& Ponssa, 2012). The distribution and orientation of the collagen fibers are well-adapted to their mechanical role (Ghosh \& Taylor, 1987; Aspden, Yarker \& Hukins, 1985; Vilarta \& Vidal, 1989; Shadwick, 1990) and support high loads (Franchi et al., 2007). Moreover, physical exercise can induce morphological and biochemical modifications that alter the biomechanical properties of the collagen bundles, resulting in tissues supporting higher tensile strength (Vilarta \& Vidal, 1989). However, changes in training regime also cause connective tissue alterations that in most cases are clearly pathological (Selvanetti, Cipolla \& Puddu, 1997; Kader et al., 2002; Shwartz, Blitz \&

392 the tibia-fibula was also affected in treated juveniles and adults. The flattening of their nuclei 393 (typically rounded) was noticeable in Leptodactylus latinasus and Phyllomedusa sauvagii 394 (Benjamin \& Ralph, 1998). The flattening of the fibrocartilage nuclei due to intense stimulus was 
395 already recorded for menisci cells (Benjamin \& Evans, 1990), and stressed areas of the tendons

396 (Carvalho \& Felisbino, 1999).

397

In the tendinous tissue, the separation of the collagen fibers was similarly accentuated in treated juveniles and adults. Our model shows that the probability to present more changes is remarkable on Rhinella arenarum. Tendon alteration has been described as one of the traits characterizing the tendinosis syndrome in mammals (Selvanetti, Cipolla \& Puddu, 1997; Kraushaar \& Nirshl, 1999; Maffulli et al., 2008; Kim et al., 2015; Thampatty \& Wang, 2017). It has been reported that exercise tends to increase collagen cross-links (Kannus et al., 1997). However, when training is extreme, collagen fibers damage, delaying collagen maturation and inhibiting such links (Kannus et al., 1997). Interestingly, the collagen cross-link can suffer a similar pattern of degradation and rupture when the tissue is immobilized (Selvanetti et al., 1997), which could explain the similar phenotypes between the tendinous tissue of our treated specimens and those reported by Abdala and Ponssa (2012) in the reduced mobility trials (Fig. 6B in Abdala \& Ponssa, 2012).

Collagen fibers arrangement in the menisci was also affected in the experimental groups. The packed arrangement pattern found in adults (both in control and treated specimens) was also

411 found in tadpoles with reduced mobility (Abdala \& Ponssa, 2010). In humans, a normal 412 meniscus is characterized by packed collagen fibers (Pauli et al., 2011), with a high 413 disorganization associated to aging and osteoarthritis (Pauli et al., 2011). The histological 414 structure of the menisci appears to be adapted to the weight-bearing function (Clark \& Ogden, 415 1983). Our results allow us to suggest that the disarrangement of the collagen fibers of the 416 menisci is not due to injury, but is instead due to young tissue developing a more packed 417 configuration when mechanical stress increases, as it was observed in both treated juvenile and 
418 adult specimens. Likewise, in the human menisci, a higher number of cells is common in young

419 tissues (Senan et al., 2011), and it decreases with age (Clark \& Ogden, 1983).

A severe flattening of the hypertrophic chondrocytes was found in treated juveniles of

Leptodactylus mystacinus. The observed injuries did not reach the magnitude of those described

422 in some specimens of anurans raised under reduced mobility (Abdala \& Ponssa, 2012; Ponssa \& Abdala, 2016). These immobilized frogs presented irregularly-shaped cells, with large lacunae, interlacunar matrix with thin boundaries and flatter than normal, resulting in a characteristic netlike appearance (Abdala \& Ponssa, 2012). The deformation of cartilaginous cells has been reported as a response to mechanical stress (Quinn et al., 1998), but is also related to an unhealthy tissue (Cook et al., 2004). Hypertrophic chondrocytes are large and round due to the mineralization of the matrix during endochondral ossification (Pacifici et al., 1990). Thus, the observed change in their shape could present interesting consequences for the normal process of endochondral ossification. tissues of reduced-mobility tadpoles (Kim, Olson \& Hall, 2009; Abdala \& Ponssa, 2012; among others), suggests that the knee-joint tissues suffer the same kind of alterations under abnormal movement stimuli (i.e. either overuse or disuse of the joints). Even considering the elastic properties of tendons, fibrocartilages and articular cartilages (Carvalho, 1995; Kannus et al., 1997), limbs overuse or disuse still cause alterations or changes in the biomechanical properties of the connective tissue of the joints (Kannus et al., 1997; Järvinen et al., 1997; Cook \& Purdan, 2009) conducting to pathologies such as osteoarthritis or tendinosis. Our results agree with the great amount of evidence associating pathologies to joint overuse, e.g. jumper knee, runner knee, 
441 of the knee tissue was similar in jumper than in walker species, in spite of the profound effect of

442 the sudden and abrupt contact between the long bones epiphyses during the jump. It should be

443 considered, however the applied mechanical test could have been either too challenging or

444 unsuitable, thus preventing the identification of differences between locomotor modes.

Both knee-joint morphology and locomotion of anurans differ from those of mammals (Kargo, Nelson \& Rome, 2002). Indeed, in rats, the range of motion is up to $145^{\circ}$ (Nagai et al., 2016); while in frogs it is about $155^{\circ}$ (Kargo, Nelson \& Rome, 2002). The hind limb bones of anurans do not lie in a single plane throughout the jump, and joint rotations are more prominent than joint extensions (Gans \& Parsons, 1966), while in mammals the kinematics of the knee consist of flexion-extension movements (Fischer et al., 2002). Despite these differences, the effects of overuse and immobility trials over the connective tissues of anurans are similar than those reported in mammals (pigs, rabbits, rats and men) and chicken (Cook et al.; 2004; Kannus, 1997). This implies that anurans could be a good model for studying abnormalities in the development caused by epigenetical stimuli, such as movement alterations (Ponssa \& Abdala, 455 2016).

Our study provides a first approximation for the understanding of tissue dynamics of the knee-joints in anurans, taking ontogeny and the different locomotors modes into account. These new data constitute a deeper approximation to the comprehension of the effect of mechanical

459 load in the development and maintenance of knee tissues in tetrapods, which could contribute to 460 the engineering of skeletal tissues (Nowlan et al., 2010). Knee alteration and pathologies are 461 caused by an interaction between excessive load (immobilization or excessive movement) (Ni et 462 al., 2015) and intrinsic factors, such as genes, age, circulating and local cytokine production, sex, biomechanics and body composition (Cook \& Purdan, 2009; Zamli \& Sharif, 2011). Therefore, 
464 studies taking these variables into account are necessary for a better understanding of the knee-

465 tissues behavior in tetrapods, and therefore for the treatment and prevention of knee-joint 466 pathologies.

467

\section{CONCLUSIONS}

469 Our data showed that anuran knee tissues suffer gradual pathological structural changes 470 when subjected to overuse, especially in adults. The changes observed include disarrangement of 471 the collagen fibers of tendons and fibrocartilage, packaging of the collagen fibers of the menisci 472 and the flattening of the fibrocartilage and the diaphysis cells. Similar effects were found in 473 anurans subjected to immobilization trials, and in joints diseases such as tendinosis and 474 osteoarthritis in mammals. Taken together, these results suggest that the knee tissues of tetrapods 475 tend to react similarly even when subjected to different types of stimuli (i.e., overuse or disuse).

476 This work represents one of the first approaches to the study of knee tissues dynamics when 477 subjected to overuse trials in anurans.

478

\section{Acknowledgements}

480 We are very grateful to Esteban J. Vera for building the treadmill belt; and to Adriana Manzano 481 (CCyTTP, CONICET, Diamante, Argentina) and Gladys Hermida (UBA, Buenos Aires, 482 Argentina), Daniela Miotti and Marcela Hernandez (Fundación Miguel Lillo, Tucuman, 483 Argentina) for their help in the preparation and interpretation of the histological samples. Helpful 484 criticism and suggestions of the reviewers improved our work in many ways. 
486

487 488

489

490

491

492

493

494

495

496

497

498

499

500

501

503

502 Astley HC, Haruta A, Roberts TJ. 2015. Robust jumping performance and elastic energy

\section{References}

Abdala V, Ponssa ML. 2012. Life in the slow lane: the effect of reduced mobility on tadpole limb development. The Anatomical Record 295:5-17.

Abdala V, Vera MC, Ponssa ML. 2017. On the presence of the patella in frogs. The Anatomical Record 300:1747-1755.

Adirim TA, Cheng TL. 2003. Overview of Injuries in the Young Athlete. Sports Medicine 33, 75-81.

Arokoski JPA, Jurvelin JS, Väätäinen U, Helminen HJ. 2000. Normal and pathological adaptations of articular cartilage. Scandinavian Journal of Medicine \& Science in Sports 10:186-198.

Aspden RM, Yarker YE, Hukins DW. 1985. Collagen orientations in the meniscus of the kneejoint. Journal of Anatomy 140:371-80.

Astley HC, Roberts TJ. 2012. Evidence for a vertebrate catapult: elastic energy storage in the plantaris tendon during frog jumping. Biol. Lett. 8:386-389.

Astley HC, Roberts TJ. 2014. The mechanics of elastic loading and recoil in anuran jumping. The Journal of Experimental Biology 217: 4372-4378. recovery from compliant perches in tree frogs. Journal of Experimental Biology 218: 3360-3363. 
504 Bailey AJ. 2001. Molecular mechanisms of ageing in connective tissues. Mechanisms of Ageing 505 and Development 122: 735-755.

506 Benjamin M, Evans EJ. 1990. Fibrocartilage. Journal of Anatomy 171:1-15.

507 Benjamin M, Tyers RN, Ralphs JR. 1991. Age-related changes in tendon fibrocartilage. Journal 508 of Anatomy 179:127-36.

509 Benjamin M, Qin S, Ralphs JR. 1995. Fibrocartilage associated with human tendons and their 510 pulleys. Journal of Anatomy 187:625-33.

511 Benjamin M, Ralphs JR. 1998. Fibrocartilage in tendons and ligaments — an adaptation to 512 compressive load. Journal of Anatomy 193:481-494.

513 Brack AS, Conboy MJ, Roy S, Lee M, Kuo CJ, Keller C, Rando TA. 2007. Increased Wnt 514 signaling during aging alters muscle stem cell fate and increases fibrosis. Science 317: 807-810.

515 Burnham, K. P., and D. P. Anderson. 2002. Model selection and multimodel inference: a 516 practical information theoretic approach. Academic Press, New York, New York, USABurnham 517 KP, Anderson DR, Huyvaert KP. 2011. AIC model selection and multimodel inference in 518 behavioral ecology : some background, observations, and comparisons. Behavioral Ecology 519 and Sociobiology, 65:23-35.

520 Carvalho HF. 1995. Understanding the biomechanics of tendon fibrocartilages. Journal of 521 Theoretical Biology 172:293-297. 
522 Carvalho HF, Felisbino SL. 1999. The development of the pressure-bearing tendon of the

523 bullfrog, Rana catesbeiana. Anatomy and Embryology 200:55-64.

524 Clark CR, Ogden JA. 1983. Development of the menisci of the human knee-joint. Morphological

525 changes and their potential role in childhood meniscal injury. The Journal of bone and Joint

526 Surgery 65:538-47.

527 Congdon KA, Hammond AS, Ravosa MJ. 2012. Differential limb loading in miniature pigs (Sus 528 scrofa domesticus): a test of chondral modeling theory. Journal of Experimental Biology $529215: 1472-1483$.

530 Cook JL, Feller JA, Bonar SF, Khan KM. 2004. Abnormal tenocyte morphology is more 531 prevalent than collagen disruption in asymptomatic athletes' patellar tendons. Journal of 532 Orthopaedic Research 22:334-8.

533 Cook JL, Purdam CR. 2009. Is tendon pathology a continuum? A pathology model to explain the 534 clinical presentation of load-induced tendinopathy. British Journal of Sports Medicine 43:409535416.

536 Coutinho EL, Gomes ARS, França CN, Salvini TF. 2002. A new model for the immobilization 537 of the rat hind limb. Brazilian Journal of Medical and Biological Research 35:1329-1332.

538 Drachman DB, Sokoloff L. 1966. The role of movement in embryonic joint development. 539 Developmental Biology 14:401-420. 
540 Ebben WP, Fauth ML, Kaufman CE, Petushek EJ. 2011. Magnitude and Rate of Mechanical

541 Loading of a variety of exercise modes. The Journal of Strength \& Conditioning Research $542 \quad 24: 213-217$.

543 Edwards LJ, Goodship AE, Birch HL, Patterson-Kane JC. 2005. Effect of exercise on age-related

544 changes in collagen fibril diameter distributions in the common digital extensor tendons of 545 young horses. American Journal of Veterinary Research 66:564-568.

546 Emerson SB. 1979. The ilio- sacral articulation in frogs: form and function. Biological Journal 547 of the Linnean Society 11:153-168.

548 Engebretsen L, Bahr R. 2007. Dolor en la rodilla. In: Bahr R \& Maelum S, eds. Lesiones 549 deportivas. Buenos Aires: Editorial Medica Panamericana, 340-352.

550 Fabrezi M, Manzano AS, Abdala V, Lobo F. 2014. Anuran Locomotion: Ontogeny and 551 Morphological Variation of a Distinctive Set of Muscles. Evolutionary Biology 4:308-326.

552 Feitosa V, Vidal BC, Pimentel ER. 2002. Optical anisotropy of a pig tendon under compression. 553 Journal of Anatomy 200:105-11.

554 Fischer MS, Schilling N, Schmidt M, Haarhaus D, Witte H. 2002. Basic limb kinematics of 555 small therian mammals. Journal of Experimental Biology 205:1315-1338.

556 Ford CA, Nowlan NC, Thomopoulos S, Killian ML. 2017. Effects of imbalanced muscle loading 557 on hip joint development and maturation. Journal of Orthopaedic Research 35:1128-1136.

558 Franchi M, Trirè A, Quaranta M, Orsini E, Ottani V. 2007. Collagen structure of tendon relates 559 to function. Scientific World Journal 7:404-20. 
560 Frost HM. 1979. Chondral Modeling Theory. Calcified Tissue International 28:181-200.

561 Frost HM. 1994. Perspectives: A vital biomechanical model of synovial joint design. The 562 Anatomical Record 240:1-18.

563 Gans C, Parsons T. 1966. On the origin of the jumping mechanism in frogs. Evolution 20:92-99.

564 Gao J, Fang J, Gong H, Gao B. 2017. Morphological and Microstructural Alterations of the 565 Articular Cartilage and Bones during Treadmill Exercises with Different Additional Weight566 Bearing Levels. Journal of Healthcare Engineering 2017: 1-9.

567 Gibson H, Edwards RH. 1985. Muscular exercise and fatigue. Sports Medicine 132:120-132.

568 Ghosh P, Taylor TK, 1987. The knee-joint meniscus. A fibrocartilage of some distinction. 569 Clinical Orthopaedics and Related Research 224:52-63.

570 Gosner KL. 1960. A simplified table for staging Anuran embryos and larvae with notes on 571 identification. Herpetologica 16:183-190.

572 Güell R, Casan R, Giménez M. 1996. Fatiga muscular periférica y respuesta ventilatoria al 573 esfuerzo en la limitación crónica al flujo aéreo (LCFA). Archivos de Bronconeumología 32:7957484.

575 Hall BK. 1975. A simple, single-injection method for inducing long term paralysis in embryonic 576 chicks, and preliminary observations of growth of the tibia. The Anatomical Record 181:767577778. 
578 Hall BK, Herring S. 1990. Paralysis and growth of the musculoskeletal system in the embryonic 579 chick. Journal of Morphology 206:45-56.

580 Hamrick MW. 1999. A chondral modeling theory revisited. Journal of Theoretical Biology $581 \quad 201: 201-208$.

582 Hebling A, Esquisatto MAM, Aro AA, Gomes L. 2014. Morphological modifications of knee 583 articular cartilage in bullfrogs (Lithobates catesbeianus) (Anura: Ranidae) during 584 postmetamorphic maturation. Zoomorphology 133:245-256.

585 Hosseini A, Hogg DA. 1991. The effects of paralysis on skeletal development in the chick 586 embryo. II. Effects on histogenesis of the tibia. Journal of Anatomy 177:169-178.

587 Ingelmark BE. 1948. The structure of tendons at various ages and under different functional 588 conditions.II. Acta Anatomica 4:13-15.

589 Järvinen M, Józsa L, Kannus P, Järvinen TL, Kvist M, Leadbetter W. 1997. Histopathological 590 findings in chronic tendon disorders. Scandinavian Journal of Medicine \& Science in Sports $591 \quad 7: 86-95$.

592 Johnson BD, Aaron EA, Babcock MA, Dempsey JA. 1996. Respiratory muscle fatigue during 593 exercise: implications for performance. Fatigue des muscles respiratoires pendant unexercice 594 physique: implications sur la performance. Medicine and Science in Sports and Exercise $595 \quad 28: 1129-1137$.

596 Jorgensen ME, Reilly SM. 2013. Phylogenetic patterns of skeletal morphometrics and pelvic 597 traits in relation to locomotor mode in frogs. Journal of Evolutionary Biology 1979:1-15. 
598 Kader D, Saxena A, Movin T, Maffulli N. 2002. Achilles tendinopathy: some aspects of basic 599 science and clinical management. British Journal of Sports Medicine 36:239-249.

600 Kahn J, Shwartz Y, Blitz E, Krief S, Sharir A, Breitel DA, Rattenbach R, Relaix F, Maire P, 601 Rountre RB, Kingsley DM, Zelzer E. 2009. Muscle contraction is necessary to maintain joint 602 progenitor cell fate. Developmental Cell 16:734-743.

603 Kannus P, Jozsa L, Natri A, Jarvinen M. 1997. Effects of training, immobilization and 604 remobilization on tendons. Scandinavian Journal of Medicine \& Science in Sports 20:67-71.

605 Kargo WJ, Nelson F, Rome LC. 2002. Jumping in frogs: assessing the design of the skeletal 606 system by anatomically realistic modeling and forward dynamic simulation. Journal of 607 Experimental Biology 1702:1683-1702.

608 Kim HT, Olson WM, Hall BK. 2009. Effects of hind limb denervation on the development of 609 appendicular ossicles in the dwarf African clawed frog, Hymenochirus boettgeri (Anura: 610 Pipidae). Acta Zoologica (Stockholm) 90:352-358.

611 Kim BS, Joo YC, Choi BH, Kim KH, Kang JS, Park SR. 2015. The effect of dry needling and 612 treadmill running on inducing pathological changes in rat Achilles tendon. Connective Tissue 613 Research 56:452-460.

614 Kjær M, Magnusson P, Krogsgaard M, Møller JB, Olesen J, Heinemeier K, Hansenm M, 615 Koskinen S, Esmarck B. 2006. Extracellular matrix adaptation of tendon and skeletal muscle to 616 exercise. Journal of Anatomy 208:445-450. 
617 Kovanen V, Suominen H, Peltonen L. 1987. Effects of aging and life-long physical training on 618 collagen in slow and fast skeletal muscle in rats. A morphometric and immuno-histochemical 619 study. Cell and Tissue Research 248: 247-55.

620 Kraushaar B, Nirschl R. 1999. Tendinosis of the elbow (tennis elbow). Clinical features and 621 findings of histological immunohistochemical, and electron microscopy studies. The Journal 622 Bone and Joint Surgery American 81:259-78.

623 Maeda T, Sakabe T, Sunaga A, Sakai K, Rivera AL, Keene DR, Sasaki T, Stavnezer E, Iannotti 624 J, Schweitzer R, Ilic D, Baskaran H. 2011. Report Conversion of Mechanical Force into TGF- b 625 Mediated Biochemical Signals. Current Biology 21: 933-941.

626 Manzano A, Abdala V, Ponssa ML, Soliz M. 2013. Ontogeny and tissue differentiation of the 627 pelvic girdle and hind limbs of anurans. Acta Zoologica (Stockholm) 94:420-436.

628 Maffulli N, Longo UG, Franceschi F, Rabitti C, Denaro V. 2008. Movin and bonar scores assess 629 the same characteristics of tendon histology. Clinical Orthopaedics Related Research 466:16056301611.

631 Michna H. 1984. Morphometric analysis of loading-induced changes in collagen-fibril 632 populations in young tendons. Cell and Tissue Research 236:465-470.

633 Murray PD, Drachman DB. 1969. The role of movement in the development of joints and related 634 structures: the head and neck in the chick embryo. Journal of Embryology and Experimental 635 Morphology 22:349-371. 
636 Nagai M, Ito A, Tajino J, Iijima H, Yamaguchi S, Zhang X, Aoyama T, Kuroki H. 2016.

637 Remobilization causes site-specific cyst formation in immobilization-induced knee cartilage

638 degeneration in an immobilized rat model. Journal of Anatomy 228:929-939.

639 Nauwelaerts S, Aerts P. 2003. Propulsive impulse as a covarying performance measure in the 640 comparison of the kinematics of swimming and jumping in frogs. Journal of Experimental 641 Biology 206:4341-4351.

642 Nauwelaerts S, Stamhuis E, Aerts P. 2005. Swimming and jumping in a semi-aquatic frog. 643 Animal Biology 55:3-15.

644 Nauwelaerts S, Aerts P. 2006. Take-off and landing forces in jumping frogs. The Journal of 645 Experimental Biology 209:66-77.

646 Ni GX, Zhou YZ, Chen W, Xu L, Li Z, Liu SY, Lei L, Zhan LQ. 2015. Different responses of 647 articular cartilage to strenuous running and joint immobilization. Connective Tissue Research $648 \quad 8207: 1-9$.

649 Nowlan NC, Bourdon C, Dumas G, Tajbakhsh S, Prendergast PJ, Murphy P. 2010. Developing 650 bones are differentially affected by compromised skeletal muscle formation. Bone 46:1275$651 \quad 1285$.

652 Nowlan NC, Dumas G, Tajbakhsh S, Prendergast PJ, Murphy P. 2012. Biophysical stimuli 653 induced by passive movements compensate for lack of skeletal muscle during embryonic 654 skeletogenesis. Biomechanics and Modeling Mechanobiology 11:207-219. 
655 Nowlan NC, Chandaria V, Sharpe J. 2014. Immobilized chicks as a model system for early-onset 656 developmental dysplasia of the hip. Journal of Orthopaedic Research 32:777-785.

657 Pacifici M, Golden EB, Oshima O, Shapiro IM, Leboy PS, Adams SL. 1990. Hypertrophic 658 chondrocytes. The terminal stage of differentiation in the chondrogenic cell lineage? Annals of 659 the New York Academy of Sciences 599:45-57.

660 Pauli C, Grogan SP, Patil S, Otsuki S, Hasegawa A, Koziol J, D’Lima DD. 2011. Macroscopic 661 and histopathologic analysis of human knee menisci in aging and osteoarthritis. Osteoarthritis 662 and Cartilage 19:1132-1141.

663 Peng C J, Lee K L, Ingersoll GM. 2002. An Introduction to Logistic Regression Analysis and 664 Reporting. The Journal of Educational Research, 96: 3-14.Peplowski M, Marsh R. 1997. Work 665 and power output in the hindlimb muscles of Cuban tree frogs Osteopilus septentrionalis during 666 jumping. The Journal of experimental biology 200: 2861-70.

667 Pitsillides AA. 2006. Early effects of embryonic movement: "a shot out of the dark". Journal of 668 Anatomy 208:417-431.

669 Ponssa ML, Abdala V. 2016. Phenotypical expression of mobility reduction during limb 670 ontogeny in frogs: the knee-joint case. PeerJ DOI 10.7717/peerj. 1730.

671 Poole AR, Kojima T, Yasuda T, Mwale F, Kobayashi M, Laverty S. 2001. Composition and 672 structure of articular cartilage. Clinical Orthopaedics Related Research 391:26-33.

673 Poulet B, Hamilton RW, Shefelbine S, Pitsillides AA. 2011. Characterizing a Novel and 674 Adjustable Noninvasive Murine Joint Loading Model. Arthritis and Rheumatism 1:137-147. 
675 Přikryl T, Aerts P, Havelková P, Herrel A, Rocek Z. 2009. Pelvic and thigh musculature in frogs 676 (Anura) and origin of anuran jumping locomotion. Journal of Anatomy 214:100-139.

677 Quinn TM, Grodzinsky AJ, Buschmann MD, Kim Y, Hunziker EB. 1998. Mechanical 678 compression alters proteoglycan deposition and matrix deformation around individual cells in 679 cartilage explants. Journal of Cell Science 111: 573-583.

680 Ralphs JR, Benjamin M. 1994. The joint capsule: structure, composition, ageing and disease. 681 Journal of Anatomy 184:503-9.

682 Reilly S, Essner R, Wren S, Easton L, Bishop P. 2015. Movement patterns in leiopelmatid frogs: 683 Insights into the locomotor repertoire of basal anurans. Behavioural Processes 121: 43-53.

684 Roddy KA, Prendergast PJ, Murphy P. 2011. Mechanical influences on morphogenesis of the 685 knee-joint revealed through morphological, molecular and computational analysis of 686 immobilised embryos. PLoS One 6: e17526.

687 Selvanetti A, Cipolla M, Puddu G. 1997. Overuse tendon injuries: Basic science and 688 classification. Operative Techniques in Sports Medicine 5:110-117.

689 Senan V, Sucheendran J, Prasad KH, Balagopal K. 2011. Histological features of meniscal 690 injury. Kerala Journal of Orthopaedics 24:30-36.

691 Shadwick RE. 1990. Elastic energy storage in tendons: mechanical differences related to 692 function and age. Journal of Applied Physiology 68:1033-1040. 
693 Sharma P, Maffulli N. 2005. Tendon Injury and Tendinopathy : Healing and Repair. Current 694 Concepts Review, 87: 17-19.

695 Shwartz Y, Blitz E, Zelzer E. 2013. One load to rule them all : Mechanical control of the 696 musculoskeletal system in development and aging. Differentiation, 86: 104-111.

697 Symonds MRE, Moussalli A. 2011. A brief guide to model selection, multimodel inference and 698 model averaging in behavioural ecology using Akaike's information criterion. Behavioral 699 Ecology and Sociobiology, 65:13-21.

700 Sullivan GE. 1966. Prolonged paralysis of the chick embryo, with special reference to effect on 701 the vertebral column. Australian Journal of Zoology 14:1-17.

702 Sun Y, Mauerhan DR, Kneisl JS, Norton HJ, Zinchenko N, Ingram J, Hanley Jr EN, Gruber HE. 703 2012. Histological examination of collagen and proteoglycan changes in osteoarthritic menisci. 704 Open Rheumatology J 6:24-32.

705 Thampatty BP, Wang JH. 2017. Mechanobiology of young and aging tendons: in vivo studies 706 with treadmill running. Journal of Orthopaedic Research, doi.org/10.1002/jor.23761

707 Tidke SN, Tidke SS. 2013. Comparative anatomy of knee-joint: class Amphibian (frog) versus 708 class Mamalia (human being). Scholars Journal Applied Medical Sciences 1:560-567.

709 Tomkoria S, Patel RV, Mao JJ. 2004. Heterogeneous nanomechanical properties of superficial 710 and zonal regions of articular cartilage of the rabbit proximal radius condyle by atomic force 711 microscopy. Medical Engineering \& Physics 26:815-822. 
712 Verbruggen SW, Loo JHW, Hayat TTA, Hajnal JV, Rutherford MA, Phillips ATM, Nowlan NC.

713 2016. Modeling the biomechanics of fetal movements. Biomechanics and Modeling

714 Mechanobiology 15:995-1004.

715 Viidik A. 1982. Age-related changes in connective tissues. In: Viidik A, ed. Lectures on

716 Gerontology, vol. 1, On Biology of Aging, part A. London: Academic Press, 173-211.

717 Vilarta R, Vidal de Campos B. 1989. Anisotropic and biomechanical properties of tendons

718 modified by exercise and denervation: aggregation and macromolecular order in collagen

719 bundles. Matrix 9:55-61.

720 Vogel KG. 2003. Tendon structure and response to changing mechanical load. Journal of

721 Musculoskeletal Neuronal Interactions 3:323-325.

722 Zamli Z, Sharif M. 2011. Chondrocyte apoptosis: A cause or consequence of osteoarthritis?

723 International Journal Rheumatic Diseases 14:159-166.

724 Zelzer E, Blitz E, Killian ML, Thomopoulos S. 2014. Tendon-to-bone attachment: from 725 development to maturity. Birth Defects Research Part C 102:101-12. 


\section{Figure captions}

727 Fig. 1. (A) Treadmill belt. (B, C) lateral and dorsal view of a specimen of Phyllomedusa sauvagii

728 walking on the treadmill. eb: elastic bands; m: motor; s: scale; pb: polycarbonate box.

729 Photograph of M.C.V.

730 Fig. 2. Squematic representation of the frog knee-joint. Sup. Zone: superficial zone; Tang. Zone:

731 tangensial zone; M: menisci; in: internal zone; me: medial zone; ex: external zone.

732 Fig 3. Histology of the knee-joint of Leptodactylus latinasus (A) Knee-joint of a juvenile 733 specimen (SVL $22.94 \mathrm{~mm}$ ), scale bar $500 \mu \mathrm{m}$; (B) detail of the fibrocartilage, scale bar $100 \mu \mathrm{m}$;

734 (C) detail of the menisci, scale bar $200 \mu \mathrm{m}$; (D) detail of the osteochondral ligament, scale bar 50 $735 \mu \mathrm{m}$; (E) detail of the graciella sesamoid, scale bar $200 \mu \mathrm{m}$. DP: distal patella; en: enthesis; e: 736 erythrocytes; f: femur; fc: fibrocartilage; gs: graciella sesamoid; lac: lateral articular cartilage; m:

737 menisci; m.g.m: muscle gracilis major; ol: osteochondral ligament; tf: tibia-fibula; t: tendon. In

738 the menisci, black arrows indicate disperse nuclei, and white arrows indicate nuclei in rows. In

739 the enthesis, the black arrow indicates the fibrocartilaginous tissue.

740 Fig 4. Histology of the knee-joint of Leptodactylus latinasus (A) Knee-joint of an adult specimen

741 (SVL30.86 mm), scale bar $200 \mu \mathrm{m}$; (B) detail of the fibrocartilage, scale bar $50 \mu \mathrm{m}$; (C) detail of

742 the menisci, scale bar $100 \mu \mathrm{m}$; (D) detail of the graciella sesamoid, scale bar $100 \mu \mathrm{m}$; (E) detail

743 of the femur epiphyses, scale bar $50 \mu \mathrm{m}$. DP: distal patella; en: enthesis; e: erythrocytes; et:

744 endochondral trabeculas; f: femur; fc: fibrocartilage; gs: graciella sesamoid; m: menisci; o:

745 osteocytes; oc: ossification center; PP: proximal patella; tf: tibia-fibula.

746 Fig 5. Scoring system showing graduals changes. Score 0 correspond to control, while Scores 1

747 and 2 correspond to overused trials. Scale bar $50 \mu \mathrm{m}$. (A) sample of L. latinasus (juvenile, SVL 
$74822.94 \mathrm{~mm}$ ), (B) sample of Phyllomedusa sauvagii (adult, SVL $70.79 \mathrm{~mm}$ ), (C) sample of $L$.

749 latinasus (adult, SVL $29.16 \mathrm{~mm}$ ), (D) sample of L. latinasus (adult, SVL $30.86 \mathrm{~mm}$ ), (E) sample

750 of L. latinasus (juvenile, SVL $22.94 \mathrm{~mm}$ ), (F) sample of L. latinasus (adult, SVL 29.16 mm), (G)

751 sample of L. latinasus (adult, SVL $30.41 \mathrm{~mm}$ ), (H) sample of Rhinella arenarum (juvenile, SVL

$75252.75 \mathrm{~mm}$ ), (I) sample of R. arenarum (juvenile, SVL $54.33 \mathrm{~mm}$ ), (J) sample of Leptodactylus

753 mystacinus (juvenile, SVL $17.58 \mathrm{~mm}$ ), (K) sample of L. mystacinus (juvenile, SVL $19.58 \mathrm{~mm}$ ),

754 (L) sample of L. latinasus (juvenile, SVL $22.94 \mathrm{~mm}$ ), (M) sample of L. mystacinus (juvenile,

755 SVL $16.51 \mathrm{~mm}$ ), (N) black bar: non observed, (O) sample of L. mystacinus (juvenile, SVL 19.58

$756 \mathrm{~mm})$.

757 Fig 6. Histology of the knee-joint of treatment specimens of (A) juveniles of L. mystacinus, scale

758 bar $200 \mu \mathrm{m}$, (B) detail of the fibrocartilage of L. mystacinus, scale bar $50 \mu \mathrm{m}$, (C) detail of the

759 femur diaphysis of L. mystacinus, scale bar $200 \mu \mathrm{m}$, (D) tibia-fibula of an adult of L. latinasus,

760 scale bar $100 \mu \mathrm{m}$, (E) detail of the fibrocartilage, scale bar $50 \mu \mathrm{m}$. DP: distal patella; et:

761 endochondral trabeculas; f: femur; fc: fibrocartilage; gs: graciella sesamoid; hc: hypertrophic

762 chondrocyte; lac: lateral articular cartilage; m: menisci; o: osteocytes; ol: osteochondral

763 ligament; tf: tibia-fibula.

764 Fig 7. Distribution of the scores in juveniles (A-E) and adults (F-I). (A and F) arrangement of the 765 collagen fibers of the fibrocartilage, (B and G) roundness of the nuclei of the fibrocartilage cells,

766 (C and $\mathrm{H}$ ) arrangement of the collagen fibers of the tendons, (D and I) arrangement of the 767 collagen fibers of the menisci, (E) shape of the hypertrophic chondrocytes. Light gray bars 768 correspond to control specimens; dark gray bar correspond to treated specimens. X axis: scores, 769 Y axis: number of specimens. 
770 Fig. 8. Boxplot of meniscus cell density in juveniles and adults, in control and treated groups. 


\section{Table $\mathbf{1}$ (on next page)}

Specimens used in the over-used experiments.

(ej) experimental juvenile.(cj) control juvenil (ea) experimental adult. (ca) control adult. SVL: snout-vent length. MCV: field number of Miriam Corina Vera. 
1 Table 1. Specimens used in the over-used experiments. (ej) experimental juvenile.(cj) control

2 juvenil (ea) experimental adult. (ca) control adult. SVL: snout-vent length. MCV: field number

3 of Miriam Corina Vera.

\begin{tabular}{|c|c|c|c|c|c|c|c|}
\hline Especie & $\begin{array}{l}\text { Identification } \\
\text { number } \\
\text { (MCV) }\end{array}$ & $\begin{array}{l}\text { SVL } \\
(\mathrm{mm})\end{array}$ & $\begin{array}{c}\text { Weight } \\
\text { (gr) }\end{array}$ & $\begin{array}{c}\text { Mean } \pm \text { SD } \\
\text { time in one } \\
\text { day } \\
(\text { min) }\end{array}$ & $\begin{array}{l}\text { Total } \\
\text { time } \\
(\min )\end{array}$ & $\begin{array}{c}\text { Mean } \pm \text { SD } \\
\text { distance in } \\
\text { one day }(m)\end{array}$ & $\begin{array}{c}\text { Total } \\
\text { distance } \\
\text { (m) }\end{array}$ \\
\hline \multirow{11}{*}{$\begin{array}{l}\text { Leptodactylus } \\
\text { latinasus }\end{array}$} & 382 & 19.23 (cj) & 1.1 & 0 & 0 & 0 & 0 \\
\hline & 262 & $21.81(\mathrm{cj})$ & 1.3 & 0 & 0 & 0 & 0 \\
\hline & 305 & $22.94(\mathrm{cj})$ & 1.3 & 0 & 0 & 0 & 0 \\
\hline & 109 & $17.93(\mathrm{ej})$ & 0.5 & $6.39 \pm 2.45$ & 230.93 & $10.47 \pm 4.02$ & 378.26 \\
\hline & 108 & 20.36 (ej) & 1.3 & $6.02 \pm 2.79$ & 216 & $9.86 \pm 4.5$ & 353.58 \\
\hline & 110 & $21.06(\mathrm{ej})$ & 1.2 & $6.42 \pm 2.02$ & 225.16 & $10.52 \pm 3.3$ & 368.8 \\
\hline & 409 & $26.91(\mathrm{ca})$ & 2.1 & 0 & 0 & 0 & 0 \\
\hline & 453 & $30.41(\mathrm{ca})$ & 2.1 & 0 & 0 & 0 & 0 \\
\hline & 451 & $30.86(\mathrm{ca})$ & 2.6 & 0 & 0 & 0 & 0 \\
\hline & 452 & 27.82 (ea) & 2.2 & $10.10 \pm 1.22$ & 681.43 & $16.55 \pm 2$ & 1116.18 \\
\hline & 450 & 29.16 (ea) & 2 & $10.15 \pm 0.76$ & 789 & $16.63 \pm 1.25$ & 1291.82 \\
\hline \multirow{14}{*}{$\begin{array}{l}\text { Leptodactylus } \\
\text { mystacinus }\end{array}$} & 82 & 18.9 (cj) & 0.6 & 0 & 0 & 0 & 0 \\
\hline & 42 & $16.51(\mathrm{cj})$ & 0.7 & 0 & 0 & 0 & 0 \\
\hline & 50 & 15.99 (cj) & 0.6 & 0 & 0 & 0 & 0 \\
\hline & 52 & $18.53(\mathrm{cj})$ & 0.5 & 0 & 0 & 0 & 0 \\
\hline & 49 & 17.61 (cj) & 0.5 & 0 & 0 & 0 & 0 \\
\hline & 98 & 19.58 (ej) & 0.6 & $1.82 \pm 0.83$ & 199 & $2.98 \pm 1.36$ & 325.38 \\
\hline & 57 & 19.95 (ej) & 0.7 & $1.55 \pm 0.45$ & 35.23 & $2.55 \pm 0.73$ & 57.71 \\
\hline & 97 & 19.58 (ej) & 0.7 & $2.58 \pm 1.15$ & 303 & $4.24 \pm 1.89$ & 496.28 \\
\hline & 99 & $18.85(\mathrm{ej})$ & 0.5 & $1.61 \pm 0.74$ & 151.4 & $2.65 \pm 1.22$ & 248.04 \\
\hline & 100 & $17.58(\mathrm{ej})$ & 0.6 & $1.72 \pm 0.64$ & 161.1 & $2.83 \pm 1.05$ & 263.88 \\
\hline & 537 & $53.82(\mathrm{ca})$ & 20 & 0 & 0 & 0 & 0 \\
\hline & 538 & $56.83(\mathrm{ca})$ & 20 & 0 & 0 & 0 & 0 \\
\hline & 539 & $57.48(\mathrm{ca})$ & 20 & 0 & 0 & 0 & 0 \\
\hline & 540 & $58.57(\mathrm{ca})$ & 25 & 0 & 0 & 0 & 0 \\
\hline
\end{tabular}




\begin{tabular}{|c|c|c|c|c|c|c|c|}
\hline & 541 & $55.29(\mathrm{ca})$ & 20 & 0 & 0 & 0 & 0 \\
\hline & 532 & $58.23(\mathrm{ea})$ & 20 & 10 & 1140 & 16.38 & 1867.32 \\
\hline & 533 & 57.13 (ea) & 45 & 10 & 1140 & 16.38 & 1867.32 \\
\hline & 534 & 57.81 (ea) & 50 & 10 & 1140 & 16.38 & 1867.32 \\
\hline & 535 & $57.16(\mathrm{ea})$ & 45 & 10 & 1140 & 16.38 & 1867.32 \\
\hline & 536 & $56.8(\mathrm{ea})$ & 25 & 10 & 1140 & 16.38 & 1867.32 \\
\hline \multirow{7}{*}{$\begin{array}{l}\text { Melanophryniscus } \\
\text { rubriventris }\end{array}$} & 438 & $37.60(\mathrm{ca})$ & 4.6 & 0 & 0 & 0 & 0 \\
\hline & 128 & $37.80(\mathrm{ca})$ & 3.9 & 0 & 0 & 0 & 0 \\
\hline & 434 & $34.95(\mathrm{ca})$ & 3.9 & 0 & 0 & 0 & 0 \\
\hline & 437 & $35.66(\mathrm{ca})$ & 3.6 & 0 & 0 & 0 & 0 \\
\hline & 436 & 33.42 (ea) & 3.5 & $10.04 \pm 0.77$ & 826.5 & $16.45 \pm 1.2$ & 1353.8 \\
\hline & 439 & 36.21(ea) & 3.9 & $8.13 \pm 2.3$ & 794.4 & $13.32 \pm 3.78$ & 1301.28 \\
\hline & 440 & 42 (ea) & 4.9 & $10.15 \pm 0.38$ & 947.56 & $16.62 \pm 0.6$ & 1552.1 \\
\hline \multirow{9}{*}{$\begin{array}{l}\text { Phyllomedusa } \\
\text { sauvagii }\end{array}$} & 76 & $25.78(\mathrm{cj})$ & 2.7 & 0 & 0 & 0 & 0 \\
\hline & 115 & $27.66(\mathrm{cj})$ & 2.5 & 0 & 0 & 0 & 0 \\
\hline & 67 & 25.78 (ej) & 2.1 & $4.91 \pm 1.56$ & 247 & $8.04 \pm 2.56$ & 405.03 \\
\hline & 81 & $26.85(\mathrm{ej})$ & 1.8 & $5.61 \pm 1.08$ & 239 & $9.20 \pm 1.78$ & 391.56 \\
\hline & 78 & 70.79 (ca) & 18.8 & 0 & 0 & 0 & 0 \\
\hline & 88 & 63.87 (ea) & 14.7 & $9.19 \pm 1.51$ & 270 & $16.29 \pm 1.61$ & 442.26 \\
\hline & 107 & 60 (ea) & 16.8 & $9.79 \pm 0.70$ & 416.46 & $16.04 \pm 1.16$ & 1501 \\
\hline & 444 & 69.9 (ea) & 20.1 & $9.84 \pm 0.64$ & 770.9 & $12.73 \pm 1.06$ & 1262.8 \\
\hline & 443 & 70 (ea) & 18.9 & $10.14 \pm 0.58$ & 794 & $16.61 \pm 0.96$ & 1300.57 \\
\hline \multirow[t]{9}{*}{ Rhinella arenarum } & 104 & $52.75(\mathrm{cj})$ & 14.5 & 0 & 0 & 0 & 0 \\
\hline & 455 & $49.43(\mathrm{cj})$ & 7.3 & 0 & 0 & 0 & 0 \\
\hline & 456 & $52.56(\mathrm{cj})$ & 12.5 & 0 & 0 & 0 & 0 \\
\hline & 446 & 24.85 (ej) & 1.7 & $9.99 \pm 1.41$ & 903.08 & $16.37 \pm 2.3$ & 1479.25 \\
\hline & 445 & $26.32(\mathrm{ej})$ & 1.5 & $10.07 \pm 0.23$ & 915.1 & $16.49 \pm 0.38$ & 1498.9 \\
\hline & 447 & 43.43(ej) & 6 & $10.04 \pm 0.56$ & 914.7 & $15.79 \pm 0.45$ & 1497.7 \\
\hline & 105 & $54.33(\mathrm{ej})$ & 14.4 & $6.43 \pm 1.53$ & 664.6 & $10.53 \pm 2.5$ & 1088.64 \\
\hline & 526 & $87.62(\mathrm{ca})$ & 105 & 0 & 0 & 0 & 0 \\
\hline & 527 & 80.09 (ca) & 60 & 0 & 0 & 0 & 0 \\
\hline
\end{tabular}




\begin{tabular}{ccccccc}
\hline 528 & $87.79(\mathrm{ca})$ & 95 & 0 & 0 & 0 & 0 \\
529 & $90.69(\mathrm{ca})$ & 95 & 0 & 0 & 0 & 0 \\
530 & $93.42(\mathrm{ca})$ & 100 & 0 & 0 & 0 & 0 \\
531 & $83.45(\mathrm{ca})$ & 75 & 0 & 0 & 0 & 0 \\
520 & $85.91(\mathrm{ea})$ & 55 & 10 & 1140 & 16.38 & 1867.32 \\
521 & $91.46(\mathrm{ea})$ & 80 & 10 & 1140 & 16.38 & 1867.32 \\
522 & $109.6(\mathrm{ea})$ & 100 & 10 & 1140 & 16.38 & 1867.32 \\
523 & $82.25(\mathrm{ea})$ & 60 & 10 & 1140 & 16.38 & 1867.32 \\
524 & $101.61(\mathrm{ea})$ & 95 & 10 & 1140 & 16.38 & 1867.32 \\
525 & $80.16(\mathrm{ea})$ & 55 & 10 & 1140 & 16.38 & 1867.32 \\
\hline
\end{tabular}

4 


\section{Table 2 (on next page)}

Criteria and scores for histological assessment of the connective tissues. 
1 Table 2. Criteria and scores for histological assessment of the connective tissues.

\begin{tabular}{lc}
\hline I. Collagen fiber arrangement of the fibrocartilage & Score \\
\hline The collagen fibers are packaged & 0 \\
The collagen fibers begin to unpack showing a lax configuration & 1 \\
Collagen fiber are more separated showing a very lax configuration & 2 \\
II. Roundness of the nuclei of the cells of the fibrocartilage &
\end{tabular}

\begin{tabular}{lc}
\hline Round nuclei of the fibrocartilage & 0 \\
The nuclei flattened showing a more ovoid shape & 1 \\
The nuclei show a very flat shape & 2 \\
III. Collagen fiber arrangement of the tendon &
\end{tabular}

$\begin{array}{ll}\text { The collagen fibers are packaged } & 0\end{array}$

The collagen fibers begin to unpack showing a lax configuration 1

Collagen fiber are more separated showing a very lax configuration 2

\section{IV.Collagen fiber arrangement of the menisci}

Marked separation of fibers

Collagen fiber becomes more packed.

Collagen fibers show a packed arrangement

\section{Shape of the hypertrophic chondrocytes of the diaphyses}

\begin{tabular}{lc}
\hline The hypertrophic chondrocytes have they typical oval or round & 0 \\
shape & 1 \\
The hypertrophic chondrocytes become flattening & 2 \\
The hypertrophic chondrocytes show a very flat shape
\end{tabular}




\section{Table 3 (on next page)}

Distribution of the scores in treated (hypermobilized) and control juveniles and adults

(0) Normal; (1)Slightly abnormal;(2) Abnormal. L.m: Leptodactylus mystacinus; L. I: Leptodactylus latinasus; M.r: Melanophryniscus rubriventris; R.a: Rhinella arenarum; P.s: Phyllomedusa sauvagii. (*) Features that were not observable in all the specimens. 
1 Table 3. Distribution of the scores in treated (hypermobilized) and control juveniles and adults.

2 Scores: (0) Normal; (1)Slightly abnormal;(2) Abnormal. L.m: Leptodactylus mystacinus; L. l:

3 Leptodactylus latinasus; M.r: Melanophryniscus rubriventris; R.a: Rhinella arenarum; P.s:

4 Phyllomedusa sauvagii. (*) Features that were not observable in all the specimens. 


\begin{tabular}{|c|c|c|c|c|c|c|}
\hline \multirow{2}{*}{$\begin{array}{l}\text { Juveniles } \\
\text { Scores }\end{array}$} & \multicolumn{3}{|c|}{ Controls (n=13) } & \multicolumn{3}{|c|}{ Treated $(n=14)$} \\
\hline & $\mathbf{0}$ & 1 & 2 & $\mathbf{0}$ & 1 & 2 \\
\hline Collagen fiber arrangement of the fibrocartilage $(*)$ & $\begin{array}{c}8 \\
(\text { L.m, L.l, } \\
\text { R.a) }\end{array}$ & $\begin{array}{c}4 \\
(L . m, \\
P . s)\end{array}$ & 0 & $\begin{array}{c}7 \\
(L . m, \\
\text { L.l,R.a) }\end{array}$ & $\begin{array}{c}4 \\
(L . m, \\
\text { L.l, } \\
\text { R.a) }\end{array}$ & 0 \\
\hline Roundness of the nuclei of the cells of the fibrocartilage $(*)$ & $\begin{array}{c}7 \\
\text { (L.m, L.l, } \\
\text { P.s, R.a) }\end{array}$ & $\begin{array}{l}3 \\
\text { (L.l. L. } \\
m)\end{array}$ & 0 & $\begin{array}{c}7 \\
(\text { L.m, L.l, } \\
\text { P.s, R.a) }\end{array}$ & $\begin{array}{c}3 \\
\text { (L.m, } \\
\text { L.l) }\end{array}$ & $\begin{array}{c}2 \\
(P . s)\end{array}$ \\
\hline Collagen fiber arrangement of the tendon & $\begin{array}{c}10 \\
\text { (L.m,L.l, } \\
\text { P.s })\end{array}$ & $\begin{array}{c}3 \\
(\text { R.a })\end{array}$ & 0 & $\begin{array}{c}8 \\
(L . m, L . l, \\
\text { P.s) }\end{array}$ & $\begin{array}{c}5 \\
(\text { L.m } \\
\text { L.l, } \\
\text { R.a) }\end{array}$ & $\begin{array}{c}1 \\
(\text { R.a } a)\end{array}$ \\
\hline Collagen fiber arrangement of the menisci $(*)$ & $\begin{array}{c}6 \\
(L . l, \\
\text { L.m,R.a, } \\
\text { P.s) }\end{array}$ & $\begin{array}{c}2 \\
\text { (L.m, } \\
\text { L.l) }\end{array}$ & $\begin{array}{c}3 \\
(L . m, L . l, \\
\text { P.s })\end{array}$ & $\begin{array}{c}5 \\
(L . m, L . l, \\
\text { P.s })\end{array}$ & $\begin{array}{c}1 \\
(L . m)\end{array}$ & $\begin{array}{c}7 \\
\text { (L.m, L.l, } \\
\text { R.a, P.s) }\end{array}$ \\
\hline Shape of the hypertrophic chondrocytes of the diaphyses & $\begin{array}{c}13 \\
\text { (L.m, L.l, } \\
\text { P.s, R.a) }\end{array}$ & 0 & 0 & $\begin{array}{c}10 \\
(L . m, L . l, \\
\text { P.s, R.a) }\end{array}$ & 0 & $\begin{array}{c}4 \\
(L . m)\end{array}$ \\
\hline Adults & \multicolumn{3}{|c|}{ Controls $(\mathrm{n}=\mathbf{2 0})$} & \multicolumn{3}{|c|}{ Treated $(n=20)$} \\
\hline Scores & $\mathbf{0}$ & 1 & 2 & $\mathbf{0}$ & 1 & 2 \\
\hline Collagen fiber arrangement of the fibrocartilage $(*)$ & $\begin{array}{c}9 \\
\text { (L.l, L.m, } \\
\text { P.s,R.a, } \\
\text { M.r) }\end{array}$ & $\begin{array}{c}10 \\
(\text { L.l, } \\
\text { L.m, } \\
\text { P.s,R.a, } \\
\text { M.r })\end{array}$ & 0 & $\begin{array}{c}8 \\
(L . m, \\
\text { P.s,R.a, } \\
\text { M.r) }\end{array}$ & $\begin{array}{c}7 \\
(\text { L.m, } \\
\text { P.s, M. } \\
\text { r, R.a) }\end{array}$ & $\begin{array}{c}5 \\
(L . l, R . a)\end{array}$ \\
\hline Roundness of the nuclei of the cells of the fibrocartilage $(*)$ & $\begin{array}{c}8 \\
\text { (L.l, L.m, } \\
\text { P.s, M.r) }\end{array}$ & $\begin{array}{c}5 \\
(L . l, \\
M . r)\end{array}$ & 0 & $\begin{array}{c}6 \\
(L . m, P . s)\end{array}$ & $\begin{array}{c}5 \\
(L . l, \\
P . s, \\
M . r)\end{array}$ & $\begin{array}{l}3 \\
(\text { L.l, L.m, } \\
\quad \text { P.s })\end{array}$ \\
\hline Collagen fiber arrangement of the tendon $(*)$ & $\begin{array}{l}10 \\
(\text { L.l, L.m, } \\
\text { R.a, M.r) }\end{array}$ & $\begin{array}{c}8 \\
(L . m, \\
R . a, \\
\text { M.r })\end{array}$ & 0 & $\begin{array}{l}9 \\
(\text { L.m,P.s, } \\
\text { M.r) }\end{array}$ & $\begin{array}{l}6 \\
(L . l, \\
\text { L.m, } \\
\text { R.a, } \\
\text { M.r })\end{array}$ & $\begin{array}{c}2 \\
(\text { R.a })\end{array}$ \\
\hline Collagen fiber arrangement of the menisci $(*)$ & $\begin{array}{c}4 \\
(L . l, L . m)\end{array}$ & $\begin{array}{c}1 \\
(L . m)\end{array}$ & $\begin{array}{c}14 \\
(\text { L.l, } \\
\text { L.m.P.s,R.a, } \\
\text { M.r })\end{array}$ & $\begin{array}{c}3 \\
(L . m, \\
\text { R.a,P.s })\end{array}$ & $\begin{array}{c}2 \\
(\text { L.m } \\
\text { R.a })\end{array}$ & $\begin{array}{c}14 \\
(L . l, \\
\text { L.m,P.s,R.a, } \\
\text { M.r })\end{array}$ \\
\hline $\begin{array}{l}\text { Shape of the hypertrophic chondrocytes of the diaphysis }\left({ }^{*}\right) \\
\text { Peer] reviewing PDF | (2017:10:21173:2:1:NEW } 6 \text { Aug 2018) }\end{array}$ & $\begin{array}{c}5 \\
\text { (R.a) }\end{array}$ & 0 & 0 & $\begin{array}{c}5 \\
(\text { R.a })\end{array}$ & 0 & $\begin{array}{c}1 \\
(P . s)\end{array}$ \\
\hline
\end{tabular}




\section{Table 4(on next page)}

Resume of multinomials logistic models and binomial logistic model (for hypertrophic chondrocytes) selections under AICc (Akaike's Information Criterion, adjusted for small sample size) for the five parameters analyzed.

In bold the model selected. mFFm: fibrocartilage fibers; mNFm: nuclei of the fibrocartilage; mFTM: tendon fibers; mFMm: menisci fibers; $\mathrm{mCHm}$, hypertrophic chondrocytes; st: stage; sp: specie; tr, treatment; md: locomotor mode; int1: intercept sp*tr; int2: intercept st*tr; int3: intercept md*tr; int4: intercept st*sp. 
1 Table 4. Resume of multinomials logistic models and binomial logistic model (for hypertrophic chondrocytes) selections under AICc

2 (Akaike's Information Criterion, adjusted for small sample size) for the five parameters analyzed. In bold the model selected. mFFm:

3 fibrocartilage fibers; mNFm: nuclei of the fibrocartilage; mFTM: tendon fibers; mFMm: menisci fibers; mCHm, hypertrophic

4 chondrocytes; st: stage; sp: specie; tr, treatment; md: locomotor mode; int1: intercept sp*tr; int2: intercept st*tr; int3: intercept md*tr;

5 int4: intercept $s t^{*} \mathrm{sp}$.

\begin{tabular}{|c|c|c|c|c|c|c|c|c|c|c|}
\hline Models & $\begin{array}{l}\text { mFFm.st. } \\
\text { tr }\end{array}$ & $\begin{array}{l}\text { mFFm.sp. } \\
\text { tr }\end{array}$ & $\mathrm{mFFm}$ & $\begin{array}{l}\text { mFFm.md. } \\
\text { st.tr }\end{array}$ & $\begin{array}{l}\text { mFFm.int } \\
2\end{array}$ & $\begin{array}{l}\text { mFFm.md. } \\
\operatorname{tr}\end{array}$ & $\begin{array}{l}\text { mFFm.sp. } \\
\text { st.tr }\end{array}$ & mFFm.int3 & $\begin{array}{l}\text { mFFm. } \\
\text { int1 }\end{array}$ & $\begin{array}{l}\text { mFFm. } \\
\text { sp.tr }\end{array}$ \\
\hline $\mathrm{dAICc}$ & 0.0 & 2.0 & 2.0 & 2.2 & 2.3 & 4.3 & 4.9 & 5.2 & 6.0 & 6.0 \\
\hline $\mathrm{df}$ & 4 & 3 & 2 & 5 & 5 & 5 & 8 & 5 & 11 & 7 \\
\hline Models & $\begin{array}{l}\text { mNFm.sp. } \\
\text { tr }\end{array}$ & $\begin{array}{l}\text { mNFm.sp. } \\
\text { st.tr }\end{array}$ & $\begin{array}{l}\text { mNFm. } \\
\text { md.tr }\end{array}$ & $\begin{array}{l}\text { mNFm.int } \\
3\end{array}$ & $\begin{array}{l}\text { mNFm. } \\
\text { md.st.tr }\end{array}$ & mNFm.tr & mNFm.int1 & mNFm & $\begin{array}{l}\text { mNFm. } \\
\text { st.tr }\end{array}$ & $\begin{array}{l}\text { mNFm.int } \\
2\end{array}$ \\
\hline dAICc & 0.0 & 2.1 & 4.7 & 6.1 & 6.7 & 9.4 & 9.7 & 9.9 & 11.6 & 13.6 \\
\hline $\mathrm{df}$ & 7 & 8 & 4 & 5 & 5 & 3 & 11 & 2 & 4 & 5 \\
\hline Models & $\begin{array}{l}\text { mFTm.sp. } \\
\text { tr }\end{array}$ & $\begin{array}{l}\text { mFTm.sp.st. } \\
\text { tr }\end{array}$ & $\begin{array}{l}\text { mFTm.int } \\
1\end{array}$ & $\begin{array}{l}\text { mFTm.md } \\
\text {.st.tr }\end{array}$ & $\begin{array}{l}\text { mFTm. } \\
\text { md.tr }\end{array}$ & $\begin{array}{l}\text { mFTm. } \\
\text { int3 }\end{array}$ & mFTm & mFTm.tr & $\begin{array}{l}\text { mFTm. } \\
\text { st.tr }\end{array}$ & $\begin{array}{l}\text { mFTm. } \\
\text { int2 }\end{array}$ \\
\hline $\mathrm{dAICc}$ & 0.0 & 0.4 & 6.8 & 37.8 & 39 & 40.9 & 45.2 & 46.1 & 47.5 & 49.5 \\
\hline
\end{tabular}




\begin{tabular}{|c|c|c|c|c|c|c|c|c|c|c|}
\hline $\mathrm{df}$ & 7 & 8 & 11 & 5 & 4 & 5 & 2 & 3 & 4 & 5 \\
\hline Models & $\begin{array}{l}\text { mFMm. } \\
\text { sp.st.tr }\end{array}$ & mFMm.sp.tr & $\begin{array}{l}\text { mFMm. } \\
\text { md.st.tr }\end{array}$ & $\begin{array}{l}\text { mFMm.int } \\
3\end{array}$ & $\begin{array}{l}\text { mFMm. } \\
\text { st.tr }\end{array}$ & $\begin{array}{l}\text { mFMm. } \\
\text { int } 2\end{array}$ & $\begin{array}{l}\text { mFMm.md. } \\
\operatorname{tr}\end{array}$ & $\begin{array}{l}\text { mFMm. } \\
\text { int1 }\end{array}$ & $\mathrm{mFMm}$ & mFMm.tr \\
\hline dAICc & 0.0 & 2.3 & 2.5 & 3.5 & 3.6 & 5.9 & 6.0 & 6.4 & 6.9 & 9.1 \\
\hline $\mathrm{df}$ & 8 & 7 & 5 & 5 & 4 & 5 & 4 & 11 & 2 & 3 \\
\hline Models & $\begin{array}{l}\text { mCH.sp.st } \\
\text {.tr }\end{array}$ & mCH.sp.tr & mCH.tr & mCH.st.tr & mCH.int1 & mCH.int4 & $\mathrm{mCH}$ & & & \\
\hline dAICc & 0.0 & 1.0 & 7.1 & 9.2 & 10.1 & 11.5 & 12.0 & & & \\
\hline $\mathrm{df}$ & 6 & 5 & 2 & 3 & 8 & 7 & 1 & & & \\
\hline
\end{tabular}




\section{Table 5 (on next page)}

Estimates of probabilities from the best models of multinomial logistic regression and binomial logistic regression of do not suffer a tissue alteration (score 0 ), suffer a slightly (score 1 ) or a high (score 2 ) issue alteration.

The best models include: the treatment and the stage (in fibrocartilage collagen fibers), the treatment and the species (in fibrocartilage nuclei and collagen fiber of the tendon), and the treatment, stage and species (in menisci fibers and hypertrophic chondrocytes). 
1 Table 5. Estimates of probabilities from the best models of multinomial logistic regression and

2 binomial logistic regression of do not suffer a tissue alteration (score 0), suffer a slightly (score

3 1) or a high (score 2) issue alteration. The best models include: the treatment and the stage (in

4 fibrocartilage collagen fibers), the treatment and the species (in fibrocartilage nuclei and collagen

5 fiber of the tendon), and the treatment, stage and species (in menisci fibers and hypertrophic

6 chondrocytes).

7

8

9

10

11

12

13

14

15 


\begin{tabular}{|c|c|c|c|c|c|c|}
\hline & Stage & Treatment & species & $\begin{array}{c}\text { Prob. } \\
\text { Score } 0 \\
\end{array}$ & $\begin{array}{c}\text { Prob. } \\
\text { Score } 1 \\
\end{array}$ & $\begin{array}{c}\text { Prob. Score } \\
2\end{array}$ \\
\hline \multirow[t]{4}{*}{$\begin{array}{l}\text { Collagen fiber arrangement of } \\
\text { the fibrocartilage }\end{array}$} & \multirow[t]{2}{*}{ juvenil } & Control & & 0.76 & 0.20 & 0.02 \\
\hline & & Treated & & 0.59 & 0.35 & 0.05 \\
\hline & \multirow[t]{2}{*}{ adult } & Control & & 0.52 & 0.40 & 0.07 \\
\hline & & Treated & & 0.32 & 0.52 & 0.14 \\
\hline \multirow{10}{*}{$\begin{array}{l}\text { Roundness of the nuclei of the } \\
\text { cells of the fibrocartilage }\end{array}$} & & \multirow[t]{5}{*}{ Control } & L. latinasus & 0.44 & 0.48 & $7.63 \mathrm{e}-02$ \\
\hline & & & L. mystacinus & 0.92 & $6.89 \mathrm{e}-02$ & $5.23 \mathrm{e}-03$ \\
\hline & & & R. arenarum & 1.00 & $7.95 \mathrm{e}-09$ & $5.604 \mathrm{e}-10$ \\
\hline & & & P. sauvagii & 0.36 & 0.53 & 0.10 \\
\hline & & & M.rubriventris & 0.41 & 0.50 & $8.58 \mathrm{e}-02$ \\
\hline & & \multirow[t]{5}{*}{ Treated } & L. latinasus & 0.16 & 0.58 & 0.25 \\
\hline & & & L. mystacinus & 0.75 & 0.22 & $2.09 \mathrm{e}-02$ \\
\hline & & & R. arenarum & 1.00 & $3.23 e-08$ & $2.27 \mathrm{e}-09$ \\
\hline & & & P. sauvagii & 0.12 & 0.56 & 0.31 \\
\hline & & & M.rubriventris & 0.14 & 0.57 & 0.27 \\
\hline \multirow{8}{*}{$\begin{array}{l}\text { Collagen fiber arrangement of } \\
\text { the tendon }\end{array}$} & & \multirow[t]{4}{*}{ Control } & L. latinasus & 0.89 & 0.10 & $1.58 \mathrm{e}-10$ \\
\hline & & & L. mystacinus & 0.95 & $4.77 \mathrm{e}-02$ & $6.95 \mathrm{e}-11$ \\
\hline & & & R. arenarum & $2.41 \mathrm{e}-08$ & 0.94 & $5.43 e-02$ \\
\hline & & & P. sauvagii & 1.0 & $7.39 \mathrm{e}-10$ & 0.00 \\
\hline & & \multirow[t]{4}{*}{ Treated } & L. latinasus & 0.52 & 0.47 & $1.26 \mathrm{e}-09$ \\
\hline & & & L. mystacinus & 0.71 & 0.28 & $5.54 \mathrm{e}-10$ \\
\hline & & & $R$. arenarum & $3.03 e-09$ & 0.68 & 0.31 \\
\hline & & & P. sauvagii & 1.00 & $5.88 \mathrm{e}-09$ & 0.00 \\
\hline \multirow{16}{*}{$\begin{array}{l}\text { Collagen fiber arrangement of } \\
\text { the menisci }\end{array}$} & \multirow[t]{8}{*}{ juvenil } & \multirow[t]{4}{*}{ Control } & L. latinasus & 0.29 & 0.21 & 0.48 \\
\hline & & & L. mystacinus & 0.64 & 0.17 & 0.18 \\
\hline & & & $R$. arenarum & 0.25 & 0.20 & 0.54 \\
\hline & & & P. sauvagii & 0.25 & 0.20 & 0.54 \\
\hline & & \multirow[t]{4}{*}{ Treated } & L. latinasus & 0.29 & 0.21 & 0.49 \\
\hline & & & L. mystacinus & 0.64 & 0.17 & 0.18 \\
\hline & & & R. arenarum & 0.25 & 0.20 & 0.54 \\
\hline & & & P. sauvagii & 0.25 & 0.20 & 0.54 \\
\hline & \multirow[t]{8}{*}{ adult } & \multirow[t]{5}{*}{ Control } & L. latinasus & 0.11 & 0.12 & 0.75 \\
\hline & & & L. mystacinus & 0.35 & 0.21 & 0.42 \\
\hline & & & $R$. arenarum & $9.52 \mathrm{e}-02$ & 0.10 & 0.79 \\
\hline & & & P. sauvagii & $9.52 \mathrm{e}-02$ & 0.10 & 0.79 \\
\hline & & & M.rubriventris & $1.20 \mathrm{e}-08$ & $1.75 \mathrm{e}-08$ & 1.00 \\
\hline & & \multirow[t]{3}{*}{ Treated } & L. latinasus & 0.11 & 0.12 & 0.76 \\
\hline & & & L. mystacinus & 0.35 & 0.21 & 0.42 \\
\hline & & & R. arenarum & $9.42 \mathrm{e}-02$ & 0.10 & 0.79 \\
\hline \multirow{2}{*}{\multicolumn{3}{|c|}{ PeerJ reviewing PDF | (2017:10:21173:2:1:NEW 6 Aug 2018) }} & P. sauvagii & $9.43 e-02$ & 0.10 & 0.79 \\
\hline & & & M.rubriventris & $1.19 \mathrm{e}-08$ & $1.73 e-08$ & 1.00 \\
\hline
\end{tabular}




\begin{tabular}{|c|c|c|c|c|c|c|}
\hline \multirow{15}{*}{$\begin{array}{l}\text { Shape of the hypertrophic } \\
\text { chondrocytes }\end{array}$} & \multirow[t]{7}{*}{ juvenil } & \multirow[t]{3}{*}{ Control } & L. latinasus & 1.00 & - & $\begin{array}{l}1.93 \mathrm{e}-20 \\
35 \mathrm{e}-10\end{array}$ \\
\hline & & & R. arenarum & 1.00 & - & $1.76 \mathrm{e}-38$ \\
\hline & & & P. sauvagii & 1.00 & - & $5.59 \mathrm{e}-10$ \\
\hline & & \multirow[t]{4}{*}{ Treated } & L. latinasus & 1.00 & - & $8.23 e-39$ \\
\hline & & & L. mystacinus & 0.2 & - & 0.80 \\
\hline & & & R. arenarum & 1.00 & - & $2.02 \mathrm{e}-28$ \\
\hline & & & P. sauvagii & 1.00 & - & $6.46 \mathrm{e}-10$ \\
\hline & \multirow[t]{8}{*}{ adult } & \multirow[t]{4}{*}{ Control } & L. latinasus & 0.98 & - & 0.02 \\
\hline & & & L. mystacinus & 0.000 & - & 1.00 \\
\hline & & & R. arenarum & 1.000 & - & $3.00 \mathrm{e}-20$ \\
\hline & & & P. sauvagii & 0.91 & - & 0.08 \\
\hline & & \multirow[t]{4}{*}{ Treated } & L. latinasus & 0.000 & - & 1.00 \\
\hline & & & L. mystacinus & 0.000 & - & 1.00 \\
\hline & & & R. arenarum & 1.000 & - & $3.45 \mathrm{e}-10$ \\
\hline & & & P. sauvagii & 0.000 & - & 1.00 \\
\hline
\end{tabular}


Figure 1

(A) Treadmill belt, $(B, C)$ Lateral and dorsal view of a specimen of Phyllomedusa sauvagii walking on the treadmill. Photograph of M.C.V.

eb, elastic bands; $m$, motor; s, scale; pb, polycarbonate box. 


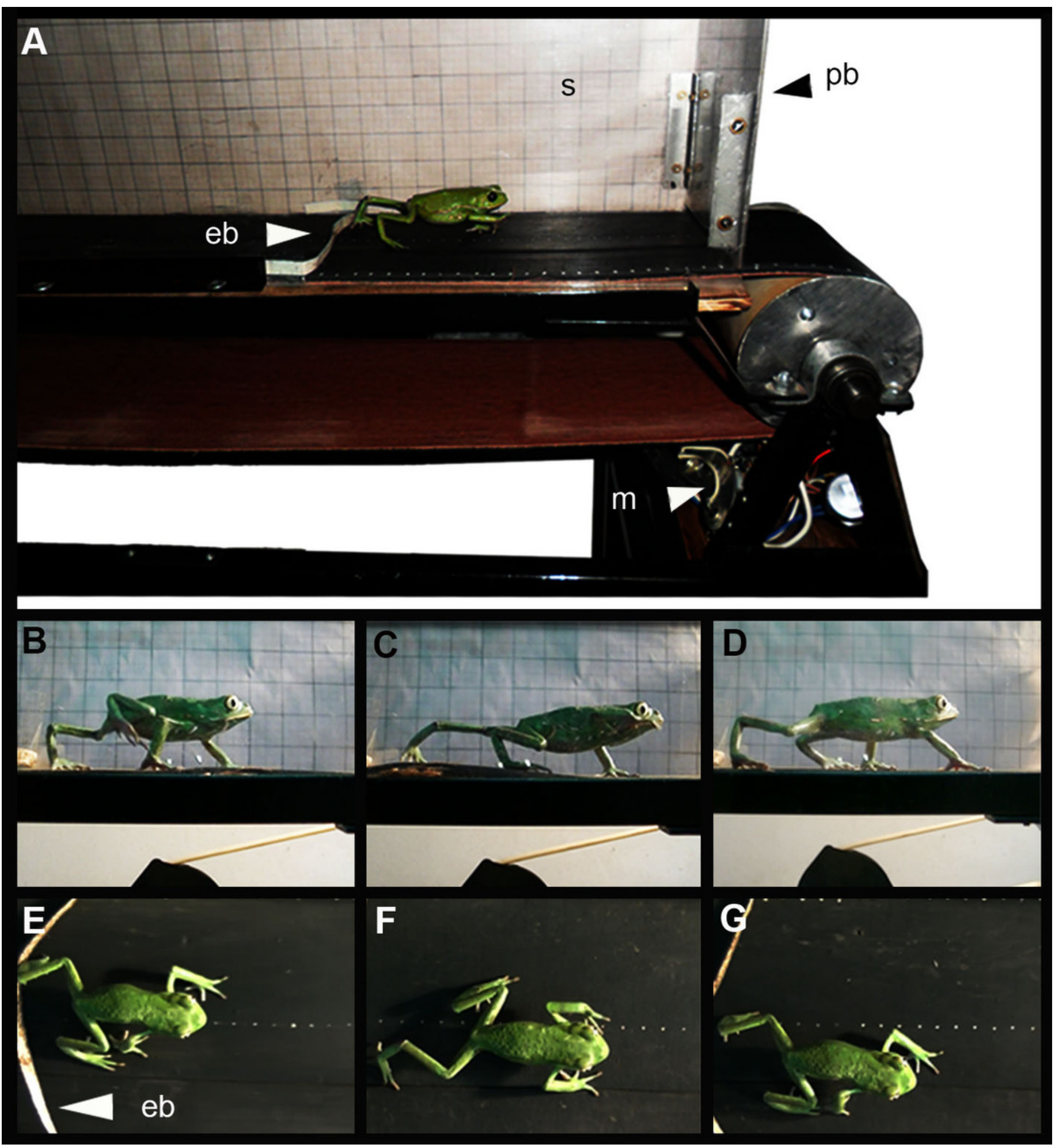




\section{Figure 2}

Squematic representation of the frog knee joint.

Sup. Zone, superficial zone; Tang. Zone, tangensial zone; M, menisci; in, internal zone; me, medial zone; ex, external zone.

*Note: Auto Gamma Correction was used for the image. This only affects the reviewing manuscript. See original source image if needed for review.

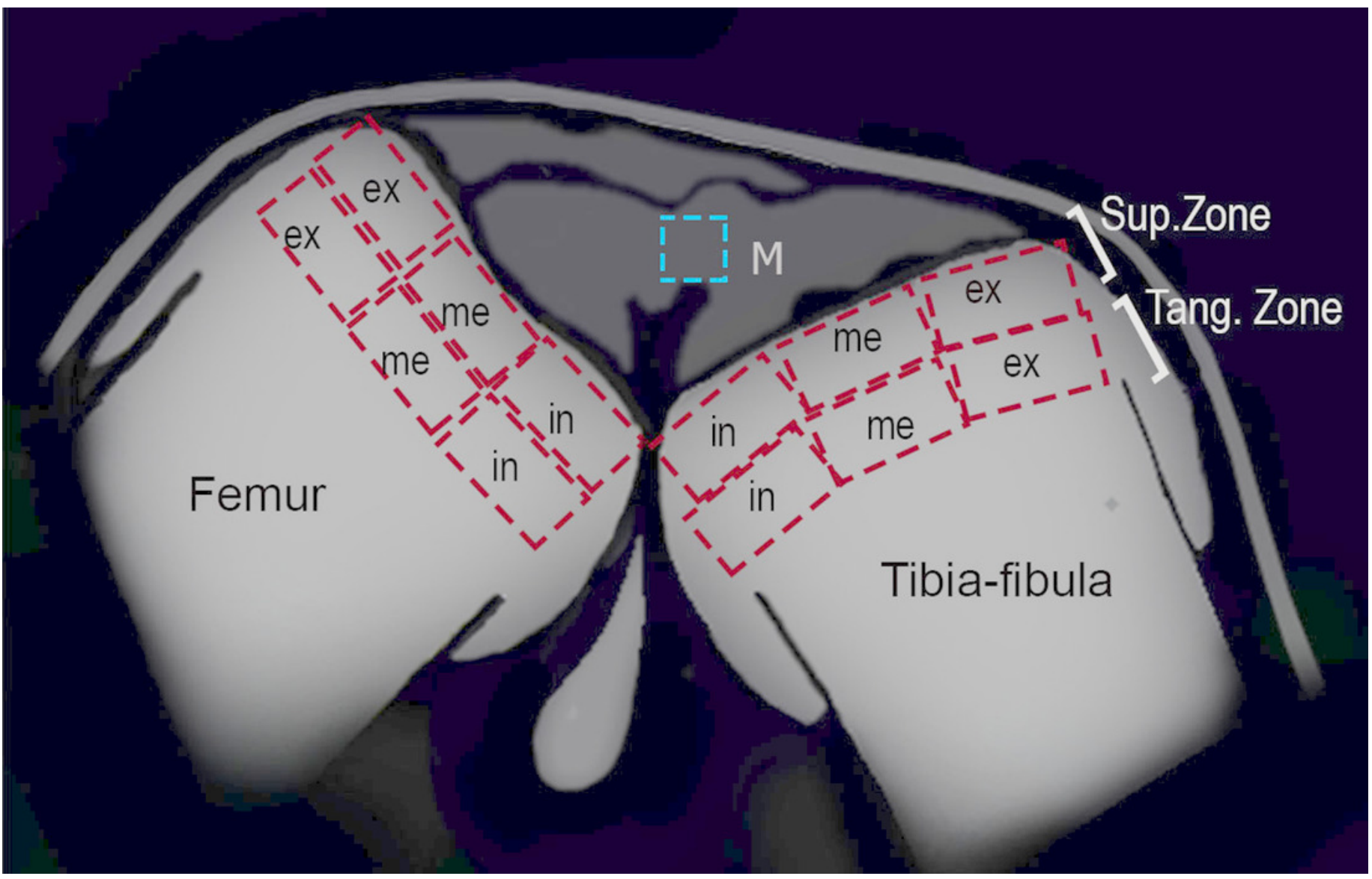




\section{Figure 3}

Histology of the knee-joint of Leptodactylus latinasus.

(A) Knee-joint of a juvenile specimen (SVL $22.94 \mathrm{~mm}$ ), scale bar $500 \mu \mathrm{m}$; (B) detail of the fibrocartilage, scale bar $100 \mu \mathrm{m}$; (C) detail of the menisci, scale bar $200 \mu \mathrm{m}$; (D) detail of the osteochondral ligament, scale

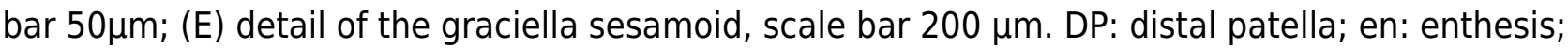
e:erythrocytes; f: femur; fc: fibrocartilage; gs: graciella sesamoid; lac: lateral articular cartilage; m:menisci; mgm: muscle gracilis major; ol: osteochondral ligament; tf: tibia-fibula; t: tendon. In the menisci, black arrows indicate disperse nuclei, and white arrows indicate nuclei in rows. In the enthesis, the black arrow indicates the fibrocartilaginous tissue.

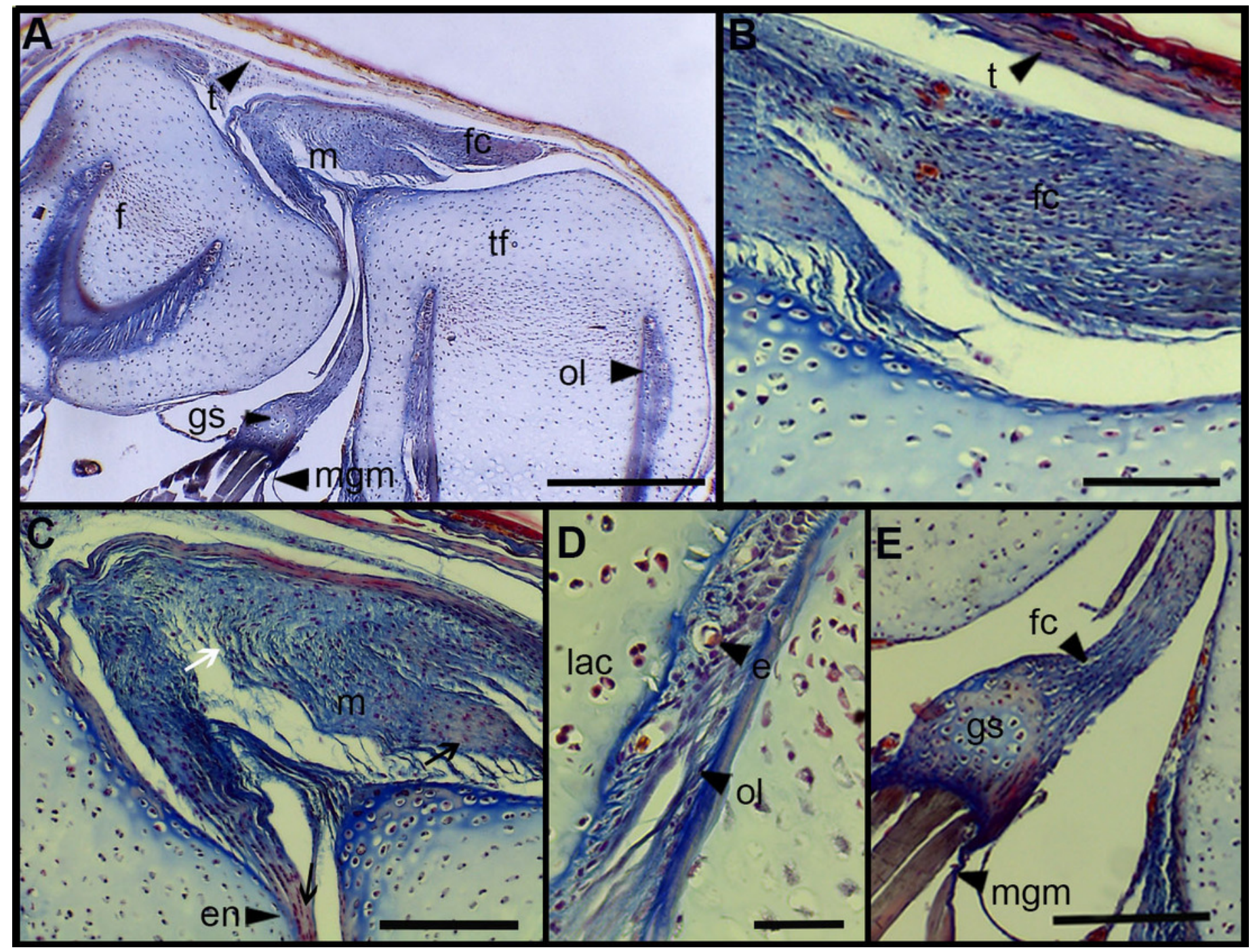




\section{Figure 4}

Histology of the knee-joint of Leptodactylus latinasus.

(A) Knee-joint of an adult specimen (SVL30.86 mm), scale bar $200 \mu \mathrm{m}$; (B) detail of the fibrocartilage, scale bar $50 \mu \mathrm{m}$;(C) detail of the menisci, scale bar $100 \mu \mathrm{m}$; (D) detail of the graciella sesamoid, scale bar 100 $\mu \mathrm{m}$; (E) detail of the femur epiphyses, scale bar $50 \mu \mathrm{m}$. DP: distal patella; en: enthesis; e:erythrocytes; et: endochondral trabeculas; f: femur; fc: fibrocartilage; gs: graciella sesamoid; m: menisci; o: osteocytes; oc: ossification center; PP: proximal patella; tf: tibia-fibula.

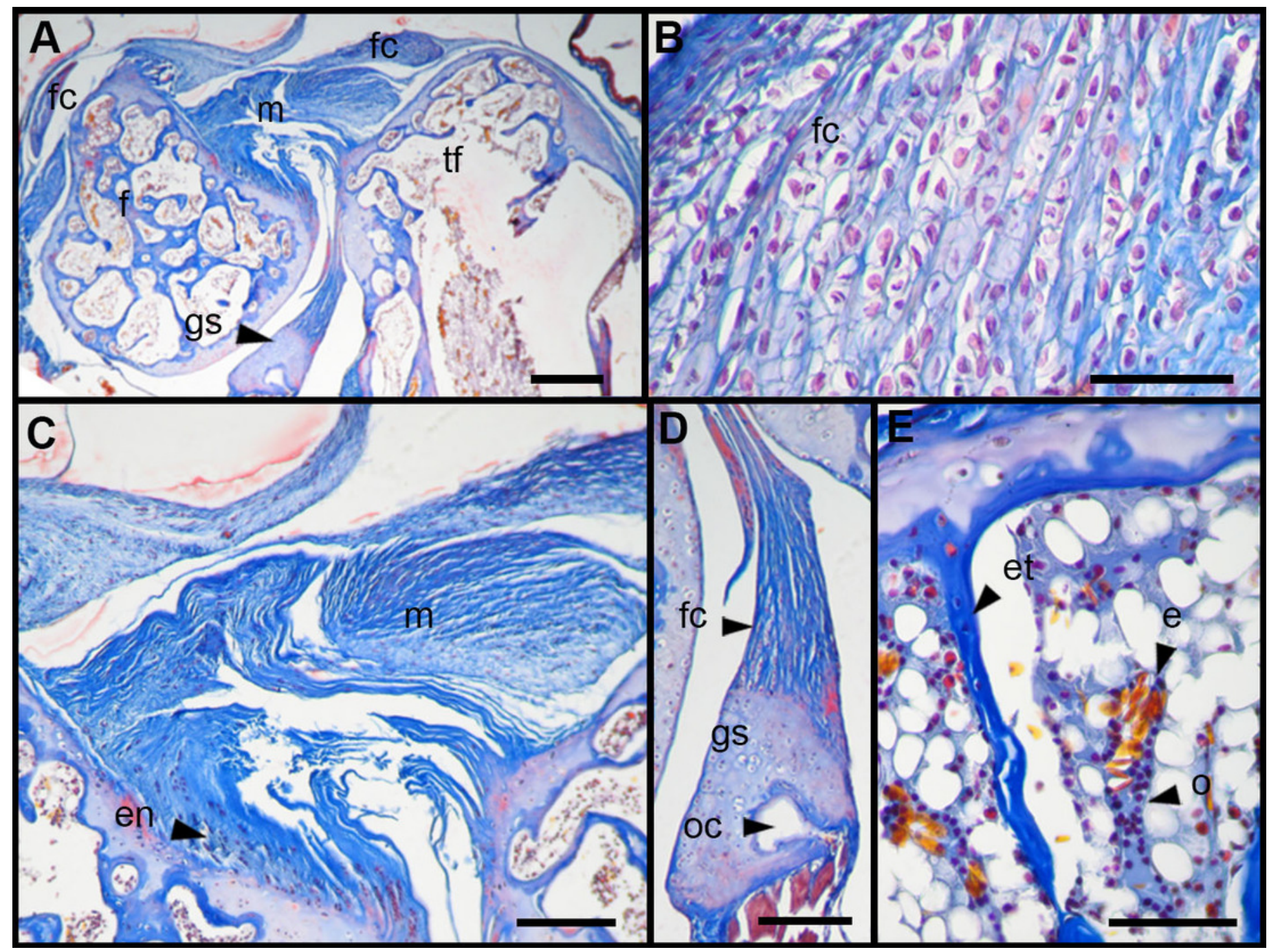




\section{Figure 5}

\section{Scoring system showing graduals changes.}

Score 0 correspond to control, while Scores land 2 correspond to overused trials. Scale bar $50 \mu \mathrm{m}$. (A) sample of L. latinasus (juvenile, SVL $22.94 \mathrm{~mm}$ ), (B) sample of Phyllomedusa sauvagii (adult, SVL 70.79 $\mathrm{mm}$ ), (C) sample of $L$. latinasus (adult, SVL $29.16 \mathrm{~mm}$ ), (D) sample of L. latinasus (adult, SVL $30.86 \mathrm{~mm}$ ), (E) sample of $L$. latinasus (juvenile, SVL $22.94 \mathrm{~mm}$ ), (F) sample of L. latinasus (adult, SVL $29.16 \mathrm{~mm}$ ), (G) sample of L. latinasus (adult, SVL $30.41 \mathrm{~mm}$ ), (H) sample of Rhinella arenarum (juvenile, SVL $52.75 \mathrm{~mm}$ ), (I) sample of $R$. arenarum (juvenile, SVL $54.33 \mathrm{~mm}$ ), (J) sample of Leptodactylus mystacinus (juvenile, SVL $17.58 \mathrm{~mm}$ ), (K) sample of L. mystacinus (juvenile, SVL $19.58 \mathrm{~mm}$ ), (L) sample of L. latinasus (juvenile, SVL $22.94 \mathrm{~mm}$ ), (M) sample of L. mystacinus (juvenile, SVL $16.51 \mathrm{~mm}$ ), (N) black bar: non observed, (O) sample of L. mystacinus (juvenile, SVL $19.58 \mathrm{~mm}$ ). 


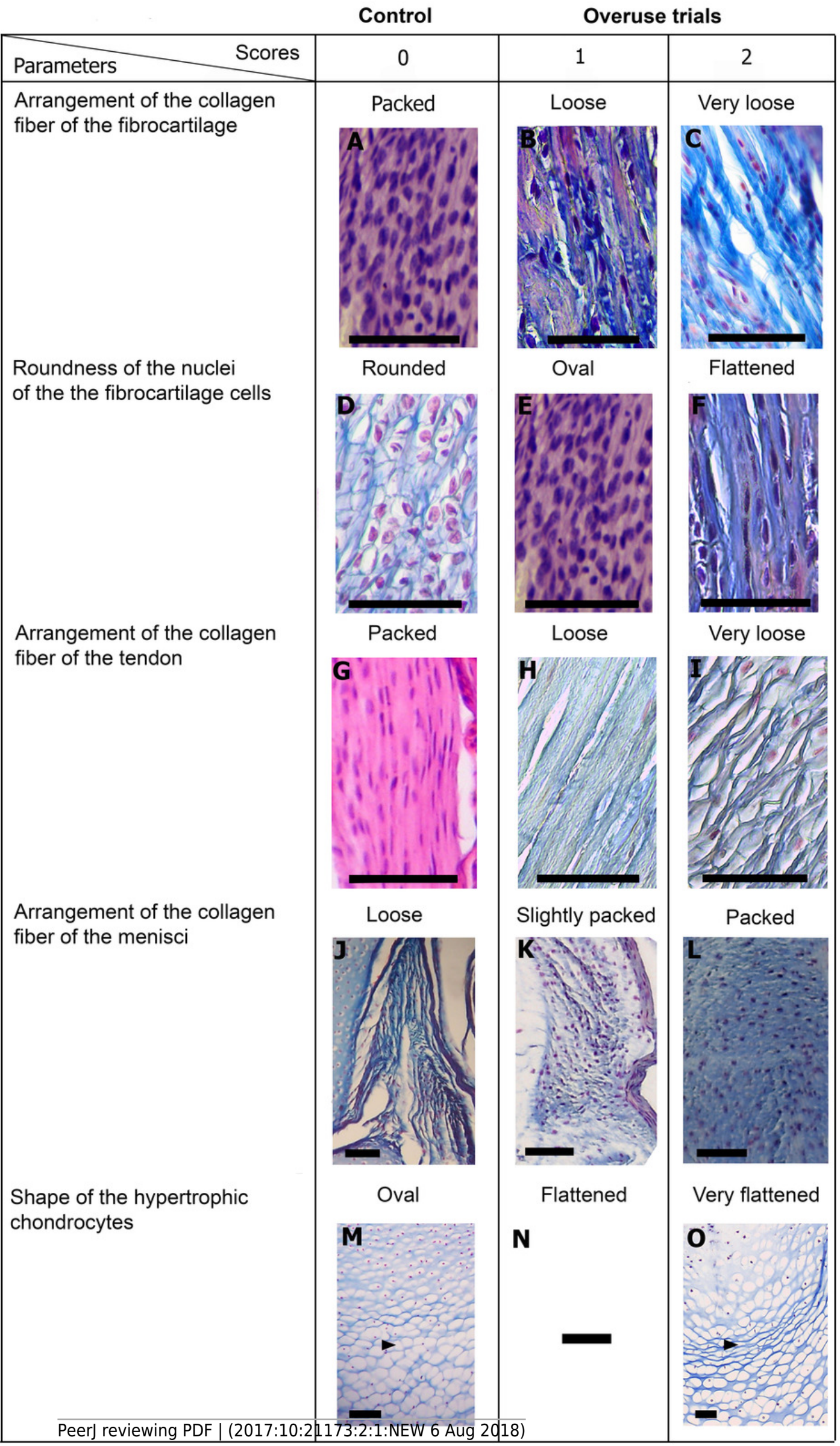




\section{Figure 6}

\section{Histology of the knee-joint of treatment specimens.}

(A) knee-joint of juvenil of Leptodactylus mystacinus, scale bar $200 \mu \mathrm{m}$, (B) detail of the fibrocartilage of L. mystacinus, showing the disarrengement of the collagen fibers and oval and flatted nucleus, scale bar 50 $\mu \mathrm{m}$, (C) detail of the femur diaphysis of $L$. mystacinus, showing flatted hypertrophic chondroccytes, scale bar $200 \mu \mathrm{m}$, (D) tibia-fibula of an adult of $L$. latinasus, scale bar $100 \mu \mathrm{m}$, (E) detail of the an altered fibrocartilage of an adult of L. latinasus, scale bar $50 \mu \mathrm{m}$. DP: distal patella; et:endochondral trabeculas; f: femur; fc: fibrocartilage; gs: graciella sesamoid; hc: hypertrophic chondrocyte; lac: lateral articular cartilage; $\mathrm{m}$ : menisci; o: osteocytes; ol: osteochondral ligament; tf: tibia-fibula. 


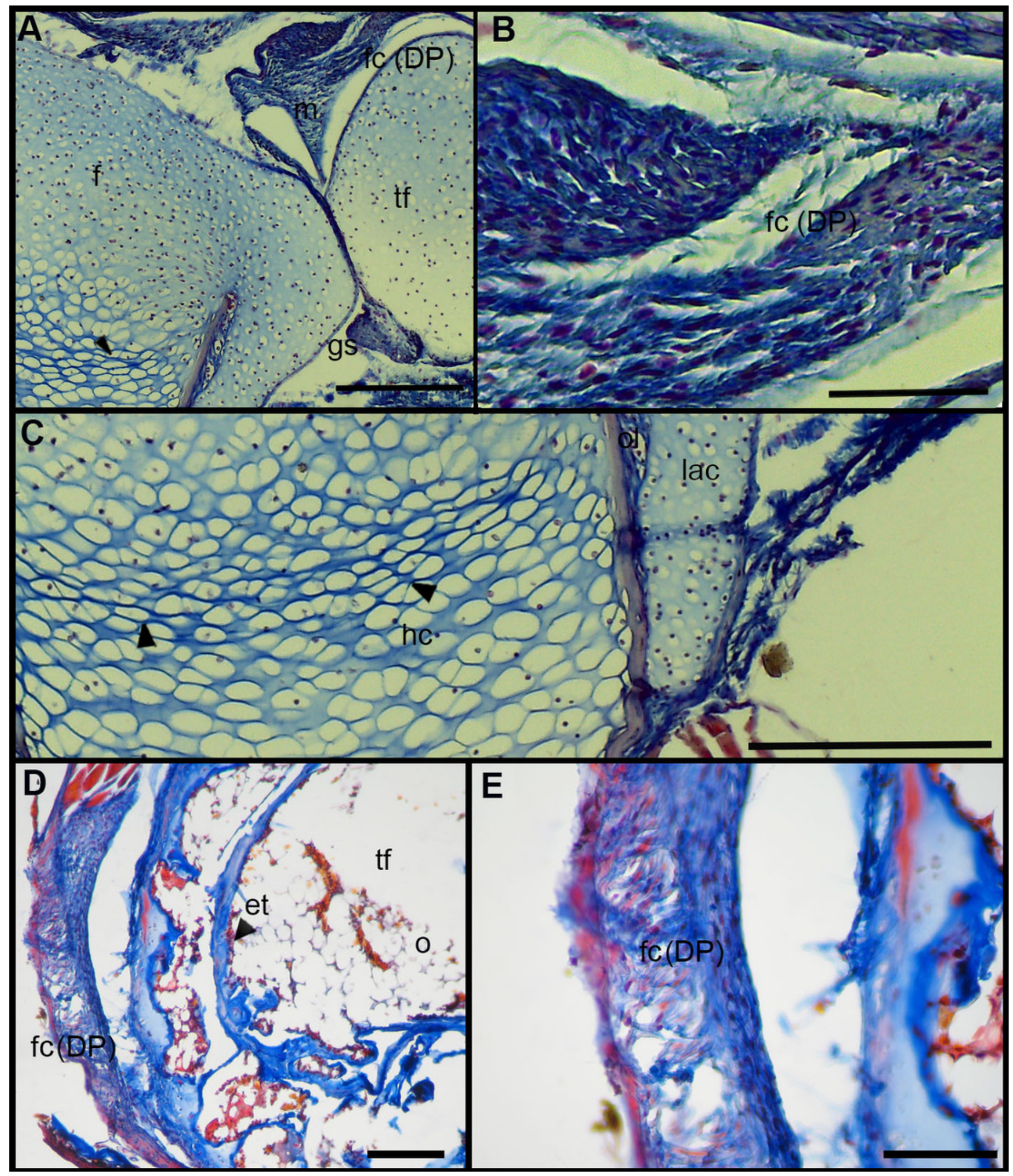




\section{Figure 7}

Distribution of the scores in juveniles.

$A-E)$ and adults (F-I). (A and F) arrangement of the collagen fibers of the fibrocartilage, (B and $G$ ) roundness of the nuclei of the fibrocartilage cells, $(\mathrm{C}$ and $\mathrm{H})$ arrangement of the collagen fibers of the tendons, $(\mathrm{D}$ and I) arrangement of the collagen fibers of the menisci, ( $E$ and F) shape of the hypertrophic chondrocytes. Light gray bars correspond to control specimens and dark gray bar correspond to treated specimens. $X$ axis: scores, $Y$ axis: number of specimens. 

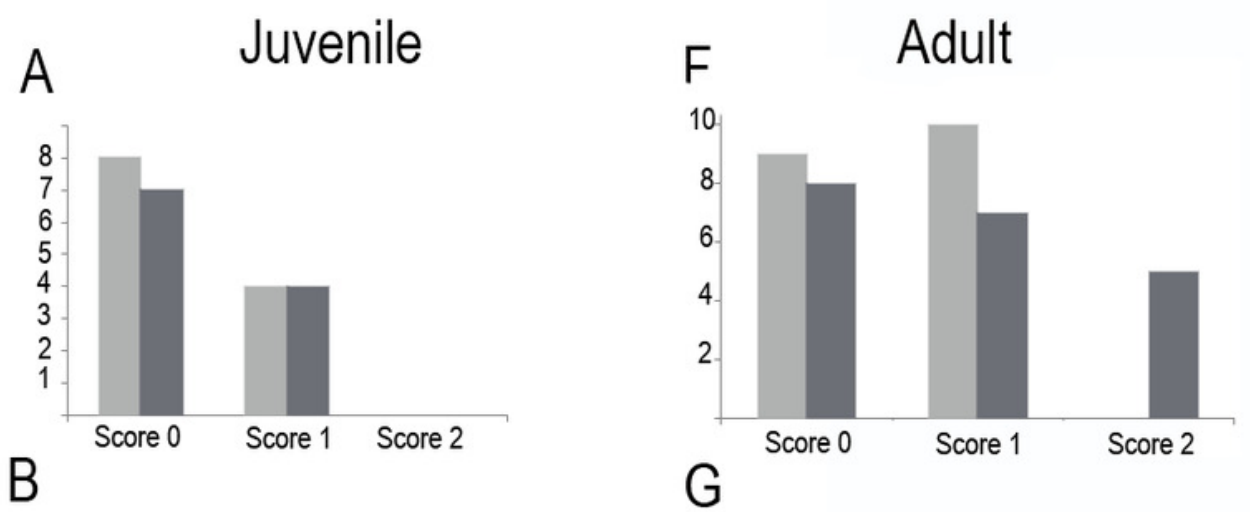

Roundness of the nuclei of the fibrocartilage cells

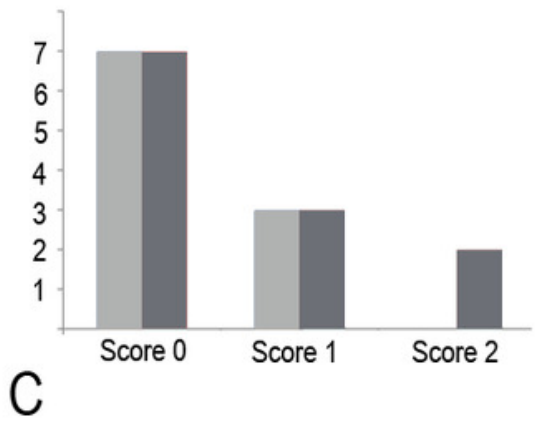

Arrangement of the collagen fibers of the tendon
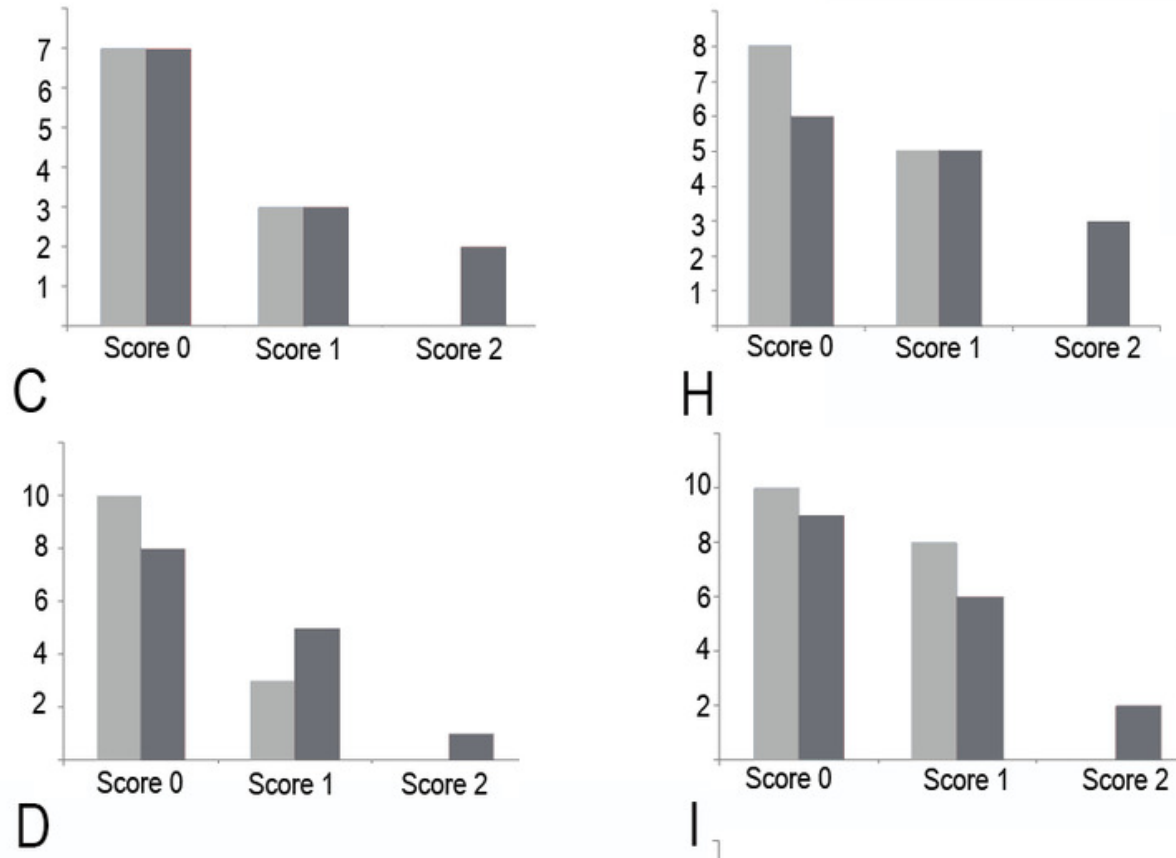

Arrangement of the collagen fibers of the menisci

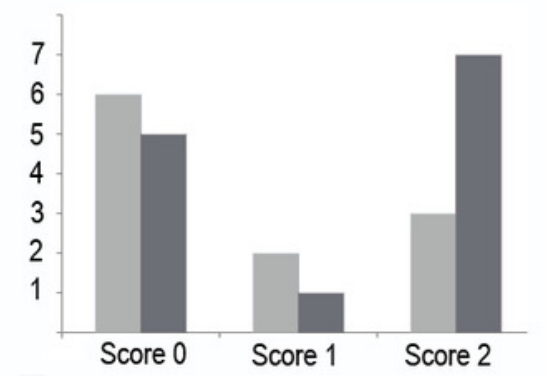

$$
\mathrm{H}
$$
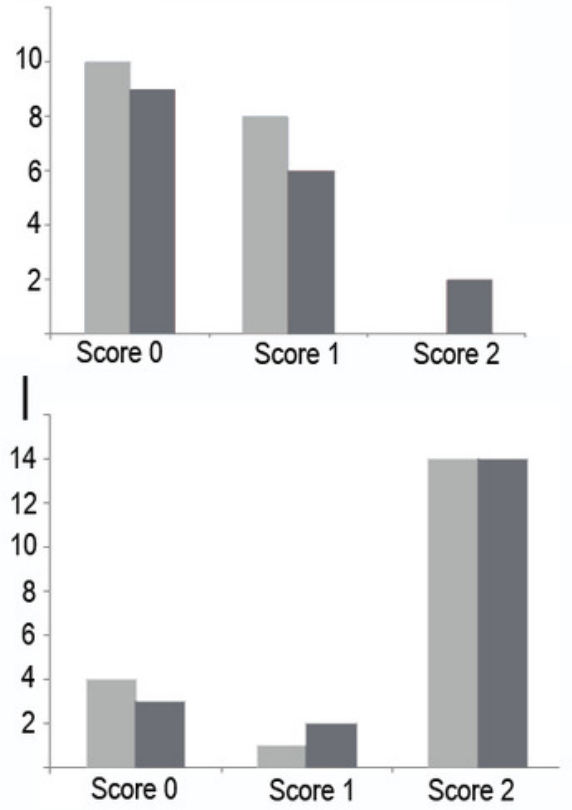

Shape of the hypertrophic chondrocytes
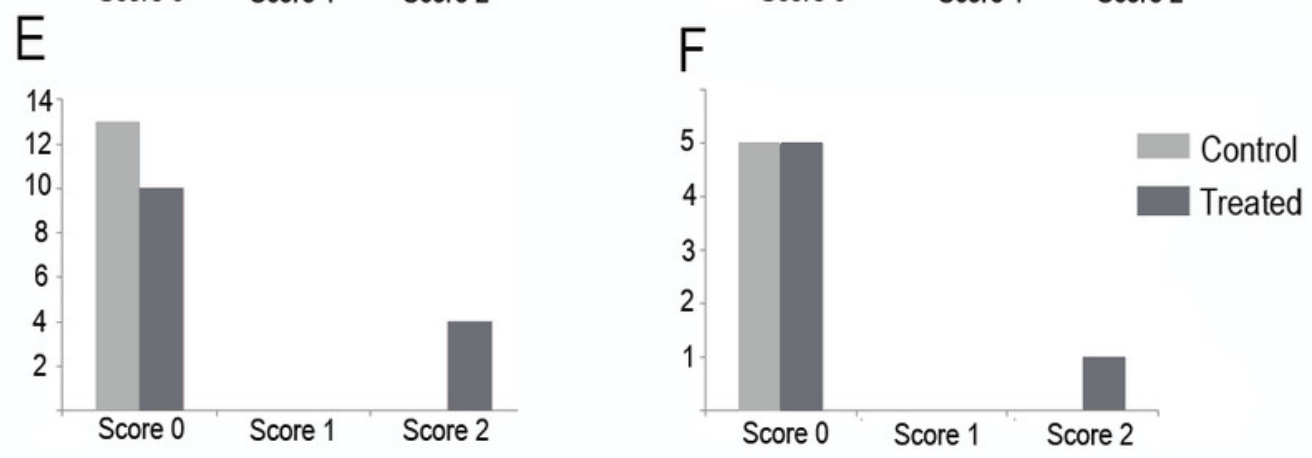
Figure 8

Boxplot of the meniscus cell density in juvenile and adults, in control and treated groups.

Juvenile

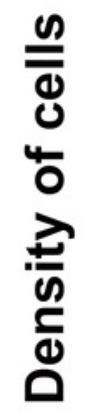

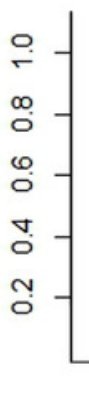

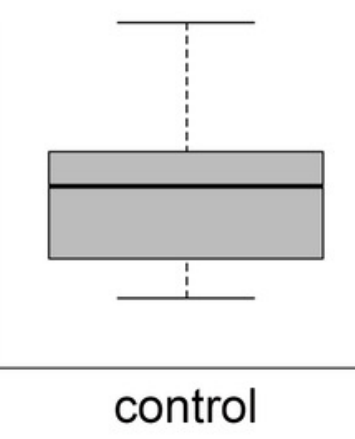

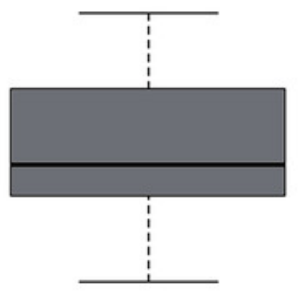

treated
Adult

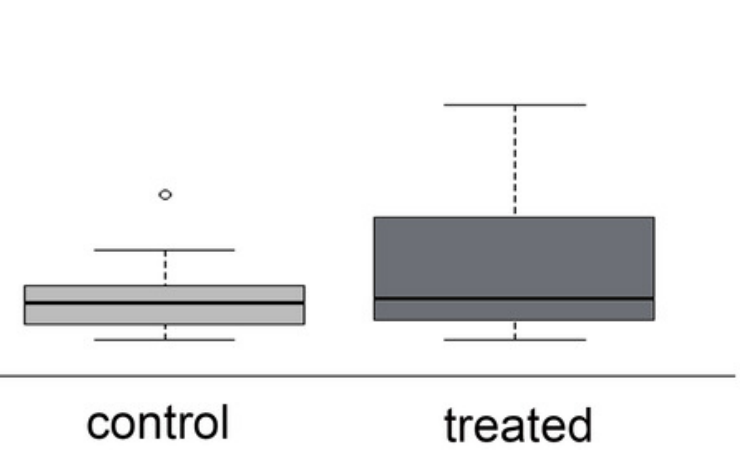

